\title{
Green Edge ice camp campaigns: understanding the processes controlling the under-ice Arctic phytoplankton spring bloom
}

\author{
Philippe Massicotte ${ }^{1,3}$, Rémi Amiraux ${ }^{1,2,3}$, Marie-Pier Amyot ${ }^{1}$, Philippe Archambault ${ }^{1,3}$, \\ Mathieu Ardyna $^{4,5}$, Laurent Arnaud ${ }^{6}$, Lise Artigue ${ }^{7}$, Cyril Aubry ${ }^{1,3}$, Pierre Ayotte ${ }^{8,9,10}$, Guislain Bécu ${ }^{1}$, \\ Simon Bélanger ${ }^{3,11}$, Ronald Benner ${ }^{12}$, Henry C. Bittig ${ }^{4,13}$, Annick Bricaud ${ }^{4}$, Éric Brossier ${ }^{14}$, \\ Flavienne Bruyant $^{1}$, Laurent Chauvaud ${ }^{2}$, Debra Christiansen-Stowe ${ }^{15}$, Hervé Claustre ${ }^{4}$, \\ Véronique Cornet-Barthaux ${ }^{16}$, Pierre Coupe ${ }^{1}$, Christine Cox $^{14}$, Aurelie Delaforge ${ }^{17}$, \\ Thibaud Dezutter ${ }^{1,3}$, Céline Dimier $^{18}$, Florent Domine ${ }^{1}$, Francis Dufour $^{1}$, Christiane Dufresne $^{3,19}$, \\ Dany Dumont $^{3,19}$, Jens Ehn ${ }^{17}$, Brent Else ${ }^{20}$, Joannie Ferland ${ }^{1}$, Marie-Hélène Forget ${ }^{1}$, Louis Fortier ${ }^{1,3}$, \\ Martí Galí $^{1,21}$, Virginie Galindo ${ }^{3,19}$, Morgane Gallinari ${ }^{2}$, Nicole Garcia ${ }^{16}$, Catherine Gérikas \\ Ribeiro $^{22,23}$, Margaux Gourdal ${ }^{1}$, Priscilla Gourvil ${ }^{24}$, Clemence Goyens ${ }^{25}$, Pierre-Luc Grondin ${ }^{1}$, \\ Pascal Guillot $^{3,26}$, Caroline Guilmette ${ }^{1}$, Marie-Noëlle Houssais ${ }^{27}$, Fabien Joux ${ }^{28}$, Léo Lacour ${ }^{1}$, \\ Thomas Lacour $^{29}$, Augustin Lafond ${ }^{16}$, José Lagunas ${ }^{1}$, Catherine Lalande ${ }^{1}$, Julien Laliberté ${ }^{1}$, \\ Simon Lambert-Girard ${ }^{1}$, Jade Larivière ${ }^{1}$, Johann Lavaud ${ }^{1}$, Anita LeBaron ${ }^{1}$, Karine Leblanc ${ }^{16}$, \\ Florence Le Gall ${ }^{22}$, Justine Legras ${ }^{16}$, Mélanie Lemire ${ }^{3,8,10,30}$, Maurice Levasseur ${ }^{1,3}$, Edouard Leymarie ${ }^{4}$, \\ Aude Leynaert $^{2}$, Adriana Lopes dos Santos ${ }^{31}$, Antonio Lourenço ${ }^{27}$, David Mah ${ }^{31}$, Claudie Marec ${ }^{1,32}$, \\ Dominique Marie ${ }^{22}$, Nicolas Martin ${ }^{27, \dagger}$, Constance Marty ${ }^{14}$, Sabine Marty ${ }^{33}$, Guillaume Massé ${ }^{1}$, \\ Atsushi Matsuoka ${ }^{1}$, Lisa Matthes ${ }^{17}$, Brivaela Moriceau ${ }^{2}$, Pierre-Emmanuel Muller ${ }^{14}$, \\ Christopher-John Mundy ${ }^{17}$, Griet Neukermans ${ }^{1,4}$, Laurent Oziel ${ }^{1,4}$, Christos Panagiotopoulos ${ }^{16}$, \\ Jean-Jacques Pangrazi ${ }^{14}$, Ghislain Picard ${ }^{34}$, Marc Picheral ${ }^{4}$, France Pinczon du Sel ${ }^{14}$, \\ Nicole Pogorzelec ${ }^{17}$, Ian Probert ${ }^{24}$, Bernard Quéguiner ${ }^{16}$, Patrick Raimbault ${ }^{16}$, Joséphine Ras ${ }^{4}$, \\ Eric Rehm ${ }^{1}$, Erin Reimer ${ }^{1}$, Jean-François Rontani ${ }^{16}$, Søren Rysgaard ${ }^{17}$, Blanche Saint-Béat ${ }^{13}$, \\ Makoto Sampei $^{35}$, Julie Sansoulet ${ }^{1}$, Catherine Schmechtig ${ }^{36}$, Sabine Schmidt ${ }^{37}$, Richard Sempéré ${ }^{16}$, \\ Caroline Sévigny ${ }^{38}$, Yuan Shen ${ }^{39, a}$, Margot Tragin ${ }^{22}$, Jean-Éric Tremblay ${ }^{1,3}$, Daniel Vaulot $^{22,31}$, \\ Gauthier Verin $^{1}$, Frédéric Vivier ${ }^{27}$, Anda Vladoiu ${ }^{27,40}$, Jeremy Whitehead ${ }^{20}$, and Marcel Babin ${ }^{1}$ \\ ${ }^{1}$ UMI Takuvik, CNRS/Université Laval, Québec G1V 0A6, QC, Canada \\ ${ }^{2}$ LEMAR, Univ Brest, CNRS, IRD, Ifremer, 29280 Plouzane, France \\ ${ }^{3}$ Québec-Océan, Université Laval, Québec G1V 0A6, QC, Canada \\ ${ }^{4}$ Laboratoire d'Océanographie de Villefranche, Sorbonne Université, CNRS, LOV, \\ 06230 Villefranche-sur-Mer, France \\ ${ }^{5}$ Department of Earth System Science, Stanford University, Stanford, CA 94305, USA \\ ${ }^{6}$ UMR 5001, IGE, CNRS, 40700 Grenoble, France \\ ${ }^{7}$ LEGOS, University of Toulouse, CNRS, CNES, IRD, UPS, 31400 Toulouse, France \\ ${ }^{8}$ Axe Santé des populations et pratiques optimales en santé, Centre de recherche du CHU de Québec - \\ Université Laval, Québec G1S 4L8, QC, Canada \\ ${ }^{9}$ Centre de toxicologie du Québec, INSPQ, Québec G1V 5B3, QC, Canada \\ ${ }^{10}$ Département de médecine sociale et préventive, Université Laval, Québec G1V 0A6, QC, Canada \\ ${ }^{11}$ Département de Biologie, Chimie et Géographie (groupes BORÉAS et Québec-Océan), Université du \\ Québec à Rimouski, 300 allée des Ursulines, Rimouski G5L 3A1, QC, Canada \\ ${ }^{12}$ Department of Biological sciences, University of South Carolina, Columbia, SC 29208, USA \\ ${ }^{13}$ Leibniz Institute for Baltic Sea Research Warnemünde, IOW, Rostock-Warnemünde, Germany
}




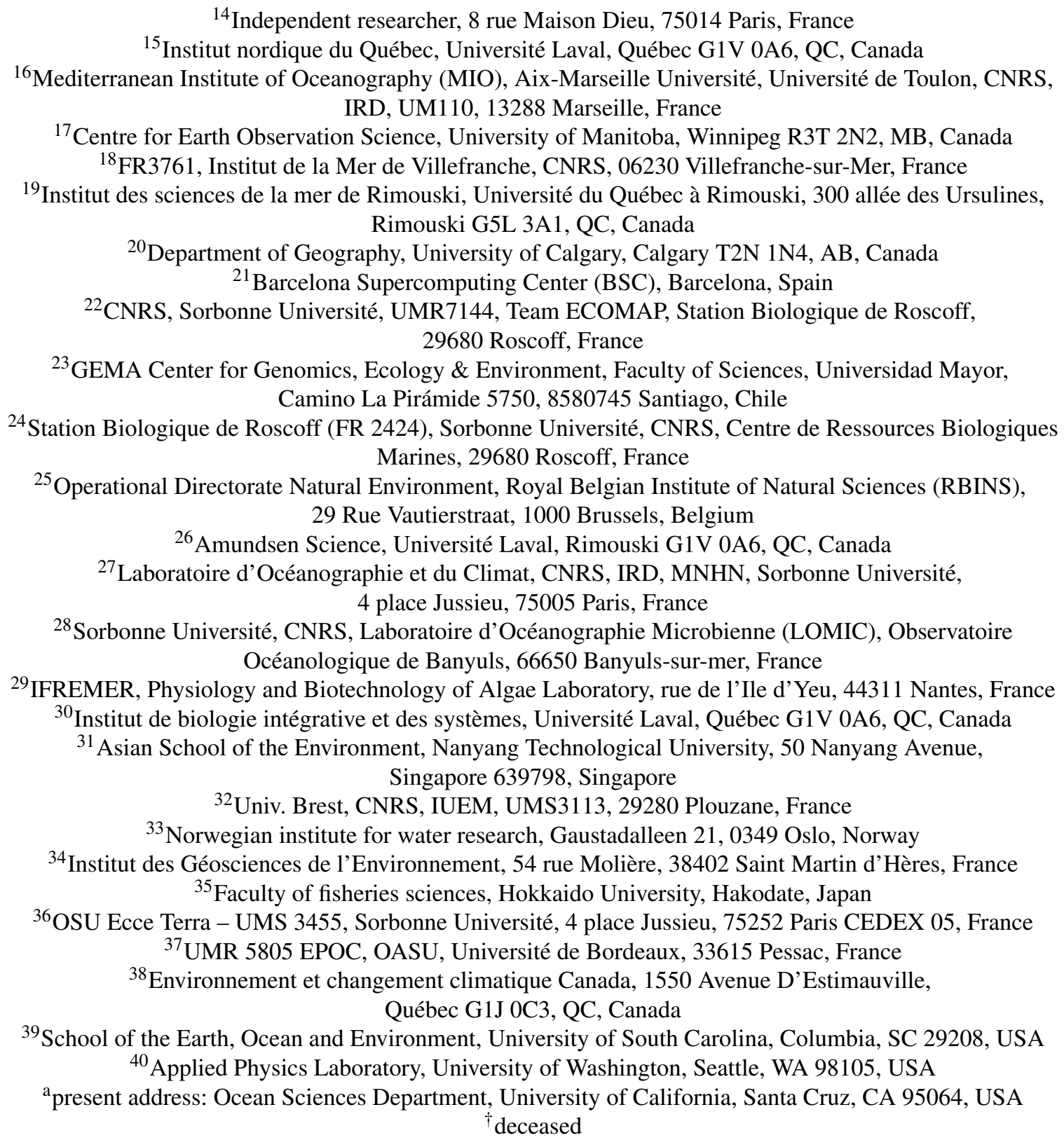

Correspondence: Philippe Massicotte (philippe.massicotte@takuvik.ulaval.ca)

Received: 4 September 2019 - Discussion started: 11 September 2019

Revised: 18 November 2019 - Accepted: 2 December 2019 - Published: 27 January 2020

\begin{abstract}
The Green Edge initiative was developed to investigate the processes controlling the primary productivity and fate of organic matter produced during the Arctic phytoplankton spring bloom (PSB) and to determine its role in the ecosystem. Two field campaigns were conducted in 2015 and 2016 at an ice camp located on landfast sea ice southeast of Qikiqtarjuaq Island in Baffin Bay $\left(67.4797^{\circ} \mathrm{N}, 63.7895^{\circ} \mathrm{W}\right)$. During both expeditions, a large suite of physical, chemical and biological variables was measured beneath a consolidated sea-ice cover from the surface to the bottom (at $360 \mathrm{~m}$ depth) to better understand the factors driving the PSB. Key variables, such as conservative temperature, absolute salinity, radiance, irradiance, nutrient concentrations, chlorophyll a concentration, bacteria, phytoplankton and zooplankton abundance and taxonomy, and carbon stocks and fluxes were routinely measured at the ice camp. Meteorological and snow-relevant variables were also monitored. Here, we present the results of a joint effort to tidy and standardize the collected datasets, which will facilitate their reuse in other Arctic studies. The dataset is available at https://doi.org/10.17882/59892 (Massicotte et al., 2019a).
\end{abstract}




\section{Introduction}

In the Arctic Ocean, the phytoplankton spring bloom (PSB) initiates the period of highest biomass primary production of the year (Sakshaug, 2004; Perrette et al., 2011; Ardyna et al., 2013). Although it was discovered that the PSB may occur more extensively and more frequently beneath a consolidated ice pack (Arrigo et al., 2012, 2014; Assmy et al., 2017), only a small number of research initiatives (e.g., Fortier et al., 2002; Galindo et al., 2014; Mundy et al., 2009, 2014; Wassmann et al., 1999; Gosselin et al., 1997) have investigated the processes controlling the Arctic PSB in the ice-covered water column. Additionally, ice algal communities play an important role within the Arctic food web and for carbon export to the benthos during the winter-spring transition (Leu et al., 2015). However, primary production within the Arctic ice pack is still poorly understood. The Green Edge project was conceived in an effort to better understand the Arctic PSB from the level of fundamental physical, chemical and biological processes to that of their interactions within the ecosystem and at spatial scales ranging from local to panArctic. Besides studying each major component of the processes controlling Arctic PSB, another objective of Green Edge was to investigate its impact on the nutrients and carbon dynamics within the ecosystem. A total of three Green Edge campaigns were conducted: two ice camp campaigns on landfast sea ice in 2015 and 2016 and an oceanographic cruise aboard the CCGS Amundsen in Baffin Bay in 2016. In this article, we present an overview of an extensive and comprehensive dataset acquired during two surveys conducted at the Green Edge ice camp.

\section{Study area, environmental conditions and sampling strategy}

The field campaigns were conducted on landfast sea ice southeast of Qikiqtarjuaq Island in Baffin Bay $\left(67.4797^{\circ} \mathrm{N}\right.$, $63.7895^{\circ} \mathrm{W}$, Fig. 1) in 2015 (15 March-17 July) and 2016 (20 April-27 July). These periods were chosen in order to capture the dynamics of the sea-ice algae and phytoplankton spring blooms, from bloom initiation to termination. The field operations took place at a location (the "ice camp") south of Qikiqtarjuaq Island where the water depth is $360 \mathrm{~m}$. Continuous records of wind speed and air temperature were made with a meteorological station: an automated Meteo Mat equipped with temperature (HC2S3) and wind (05305-L) sensors (Campbell Scientific) positioned near $(<100 \mathrm{~m})$ the tent (Polarhaven, Weatherhaven), in which water sampling was carried out. During the sampling periods, the study site experienced changes in snow cover and ice thickness (Fig. 2). In 2015, the snow and ice thickness at the monitoring spot varied between 2 and $40 \mathrm{~cm}$ (mean of $21 \mathrm{~cm}$ ) and 103 and $136 \mathrm{~cm}$ (mean of 121), respectively. In 2016, the snow and

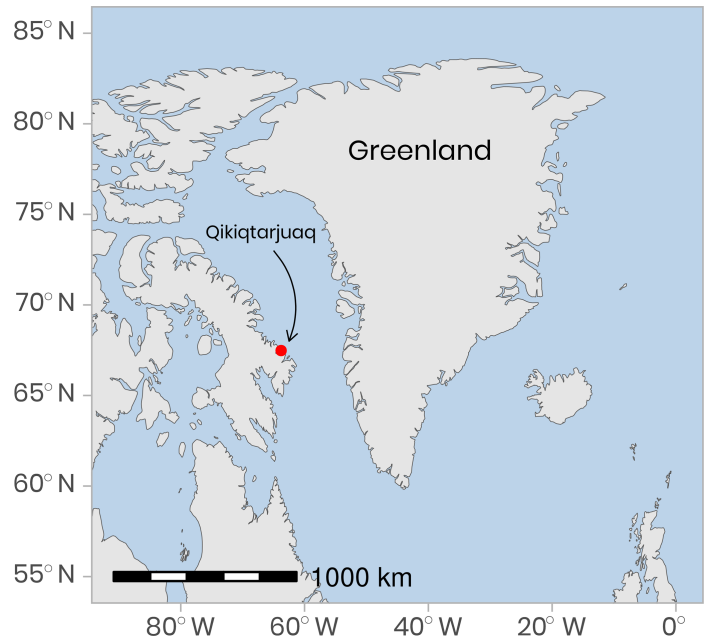

Figure 1. Location of the ice camp located near Qikiqtarjuaq Island in Baffin Bay. The projection used is EPSG-4326.

ice thickness varied between 0.3 and $49 \mathrm{~cm}$ (mean of $19 \mathrm{~cm}$ ) and 106 and $149 \mathrm{~cm}$ (mean of $128 \mathrm{~cm}$ ), respectively. For both years, snowmelt began at the beginning of June and lasted for approximately 2 to 3 weeks (Oziel et al., 2019). Water sampling was usually carried out every $2 \mathrm{~d}$ through a $1 \times 1 \mathrm{~m}$ hole in the ice pack shielded by the tent. For the analysis of nutrient concentrations, photosynthetic parameters, primary production, chlorophyll $a$ ( $\operatorname{chl} a$ ), phytoplankton taxonomy, and carbon stocks, such as dissolved organic carbon (DOC) and particulate organic carbon (POC); water samples were collected at $1.5,5,10,20,40$ and $60 \mathrm{~m}$ using 10 or $20 \mathrm{~L}$ Niskin bottles. Details about specific measurements, such as zooplankton and bacteria abundances, are provided in the following sections.

\section{Data quality control and data processing}

Different quality control procedures were adopted to ensure the integrity of the data. First, the raw data were visually screened to eliminate errors originating from the measurement devices, including sensors (systematic or random) and errors inherent from measurement procedures and methods. Statistical summaries such as average, standard deviation and range were computed to detect and remove anomalous values in the data. Following from this, data were checked for duplicates and remaining outliers. Once raw measurements were cleaned, data were structured and regrouped into plain text comma-separated (CSV) files. Each of these files was constructed to gather variables of the same nature (e.g., nutrients). In each of these files, a minimum number of variables (columns) were always included so the different datasets could be easily merged together (Table 1). More than 120 different variables were measured dur- 
Table 1. Descriptions of the minimal variables included in each dataset (i.e., in each CSV file).

\begin{tabular}{ll}
\hline Variable & Description \\
\hline date & Sampling date (UTC) \\
latitude & Latitude of the sampling location (degree decimals) \\
longitude & Longitude of the sampling location (degree decimals) \\
sample_type & Origin of the water ("water", "ice", "melt pond") \\
sample_source & Source of the water ("niskin", "underice" "0-1 cm", "0-3 cm", "3-10 cm", "rosette") \\
\hline depth_m & Depth at which measurement was made \\
snow_thickness & Qualitative value describing the snow cover under which measurement was made ("thin_snow", "thick_snow”) \\
mission & Mission identifier ("ice_camp_2015", "ice_camp_2016") \\
pi & Name(s) of the principal investigator(s) responsible of the measured variable \\
\hline
\end{tabular}

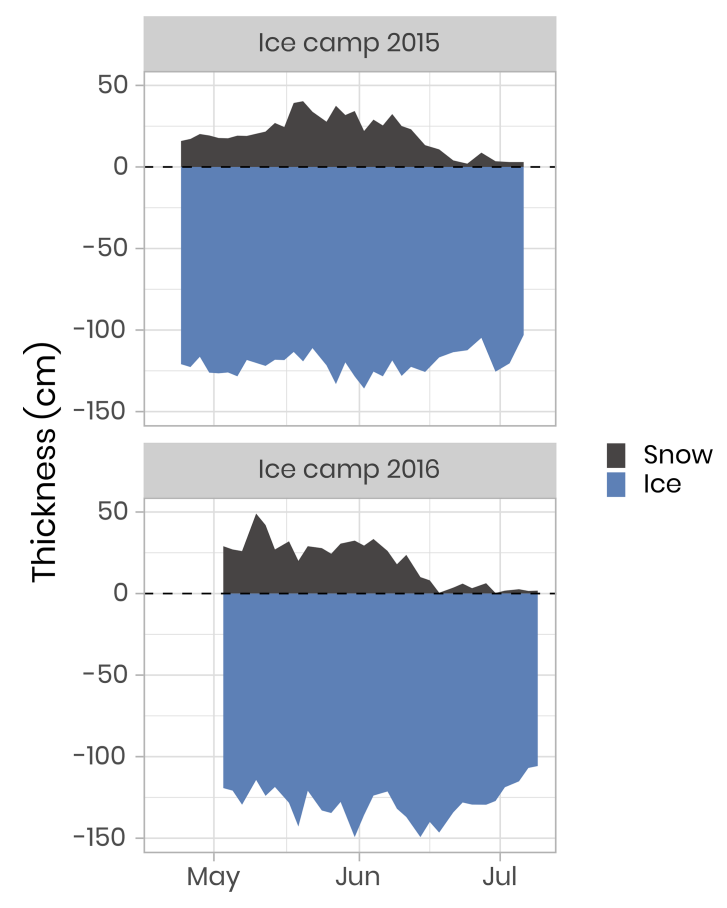

Figure 2. Temporal evolution of the snow and sea-ice thickness for both ice camp missions. The dashed horizontal line represents the snow-ice interface.

ing the Green Edge landfast-ice expeditions. The complete list of variables is presented in Table 2 and detailed metadata information can be found in the LEFE-CYBER online repository (http://www.obs-vlfr.fr/proof/php/GREENEDGE/ greenedge.php, last access: 2 December 2019). The processed and tidied version of the data is hosted at SEANOE (SEA scieNtific Open data Edition) under the CC-BY license (https://www.seanoe.org/data/00487/59892/, last access: 2 December 2019, Massicotte et al., 2019a). In the following sections, we present a subset of these variables along with the methods used to collect and measure them. For each of these variables, time series or vertical profiles are used to describe the data. Data cleaning and visualization were per- formed with R 3.6.1 (R Core Team, 2019). The code used to produce the figures and the analysis presented in this paper is available under the GNU GPLv3 license (https://github. com/PMassicotte/greenedge-icecamp-data-paper, last access: 2 December 2019). The code used to process and tidy the data provided by each researcher is also publicly available (https://gitlab.com/Takuvik/greenedge-database, last access: 2 December 2019) under the GNU GPLv3 license.

\section{Data description: an overview}

\subsection{Physical data}

Some meteorological variables were measured during both campaigns. Starting on 27 March 2015, air temperature, relative humidity, wind speed and snow depth were measured. Data were recorded using a CR1000 Campbell data logger. Field measurements were performed most days to obtain snow physical variables. These included vertical profiles of snow density and specific surface area with $1 \mathrm{~cm}$ vertical resolution and visual determination of snow stratigraphy. Snow spectral albedo in the $400-1100 \mathrm{~nm}$ spectral range was also measured during these field measurements. Snow measurements are detailed in Verin et al. (2019).

Underwater conductivity, conservative temperature and depth (CTD) vertical profiles were measured using a SeaBird SBE19plusV2 CTD system (factory-calibrated prior to the expedition) deployed from inside the Polarhaven tent between the surface and a $350 \mathrm{~m}$ depth. The data were post-processed according to the standard procedures recommended by the manufacturer and averaged into $1 \mathrm{~m}$ vertical bins. During the sampling periods, absolute salinity $\left(S_{\mathrm{A}}\right)$ was generally greater than $31.5 \mathrm{~g} \mathrm{~kg}^{-1}$ (range of $4-34.4 \mathrm{~g} \mathrm{~kg}^{-1}$ ). Flushes of freshwater at the ocean surface due to snow and ice melt started slowly at the beginning of June with the largest peaks and pulses taking place late June when absolute salinity decreased to approximately $4 \mathrm{~g} \mathrm{~kg}^{-1}$ (Fig. 3). Note that the new standard of absolute salinity is used for the remainder of this paper (Oziel et al., 2019; Randelhoff et al., 2019). 


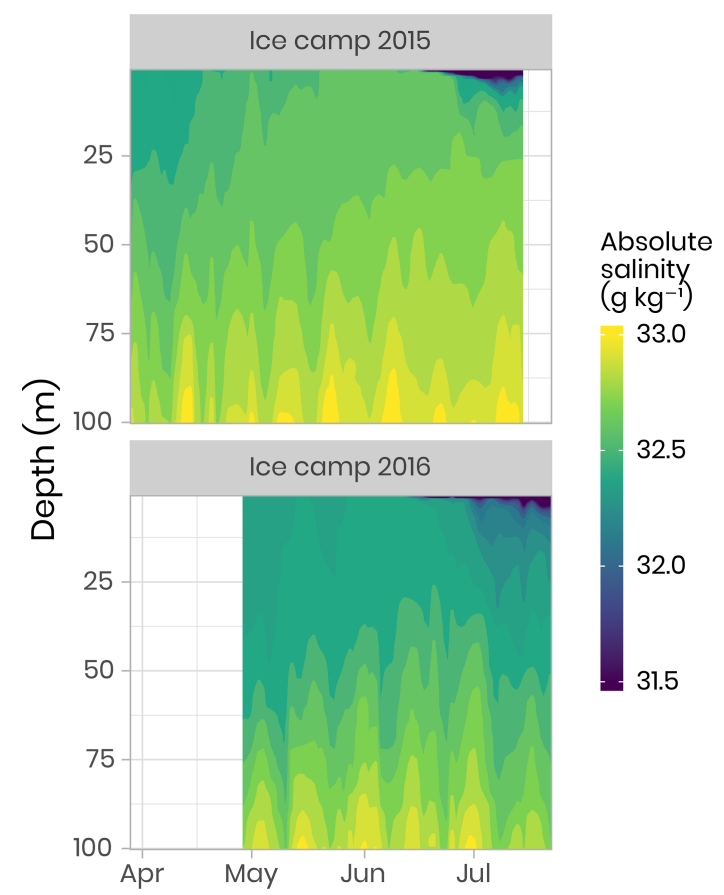

Figure 3. Temporal evolution of the salinity in the first $100 \mathrm{~m}$ of the water column for both campaigns. Note that, for visualization purposes, salinity below $31.5 \mathrm{~g} \mathrm{~kg}^{-1}$ has been binned to $31.5 \mathrm{~g} \mathrm{~kg}^{-1}$. Note that salinity as low as $4 \mathrm{~g} \mathrm{~kg}^{-1}$ was observed during flushes of freshwater at the ocean surface due to snow and ice melt (dark blue color in the figure).

Ocean current profiles in the water column were measured using a downward-looking $300 \mathrm{kHz}$ Sentinel Workhorse Acoustic Doppler Current Profiler (ADCP, RDI Teledyne) mounted directly beneath the sea-ice bottom. The study site was dominated by seawater originating from the Arctic Ocean modulated by spring-neap tidal cycles (14 d) and semidiurnal M2 periods $(\approx 12.4 \mathrm{~h})$. Vertical profiles of water column turbulence were measured on 23 June 2016 during a spring tidal cycle $(\approx 12.4)$ using a self-contained autonomous microprofiler (SCAMP, Precision Measurement Engineering, California, USA). The turbulence profile (i.e., a median profile of the rate of dissipation of turbulent kinetic energy, $\epsilon$ ) showed a mixing layer depth of about 20 $25 \mathrm{~m}$, characterized by an elevated dissipation rate with values above $10^{-8} \mathrm{~W} \mathrm{~kg}^{-1}$. The reader is referred to the paper by Oziel et al. (2019) for detailed methods, visualization and discussion of the CTD, SCAMP and ADCP data.

Vertical profiles (surface to $200 \mathrm{~m}$ ) of CTD and bio-optical properties were measured every hour during a M2 tidal cycle on 9 June 2016 (an example of modeled surface tidal height vs. time is shown in Fig. A1). These observations (Fig. 4) illustrate that internal tidal waves caused large vertical isopycnal displacements (20-30 m) of all observed physical and biogeochemical properties below $50 \mathrm{~m}$ depth across the semidiurnal M2 period. Hence, as vertical profiles of physical and bio-optical variables were measured at approximately the same time each day, properties (assuming they follow a conservative mixing behavior) will appear to be vertically displaced. Therefore, when comparing properties from vertical profiles taken at the ice camp, we suggest that comparisons of profile variables should be made on isopycnal (constant density) coordinates, rather than depth coordinates (Fig. 4).

\subsection{Underwater bio-optical data}

\subsubsection{Radiance and irradiance measurements with ICE-Pro}

A total of 173 and 89 vertical radiometric profiles were measured in 2015 and 2016, respectively, using a factorycalibrated ICE-Pro (an ice floe version of the CompactOptical Profiling System, C-OPS, from Biospherical Instruments Inc.). The ICE-Pro was equipped with radiometers for both downward plane irradiance $\left(E_{\mathrm{d}}, \mathrm{W} \mathrm{m}^{-2} \mathrm{~nm}^{-1}\right)$ and either upward irradiance $\left(E_{\mathrm{u}}, \mathrm{W} \mathrm{m}^{-2} \mathrm{~nm}^{-1}\right)$ in 2015 or upward radiance $\left(L_{\mathrm{u}}, \mathrm{W} \mathrm{m}^{-2} \mathrm{sr}^{-1} \mathrm{~nm}^{-1}\right)$ in 2016 . The profiles were taken at two sites, separated by approximately $40 \mathrm{~m}$. In order to perform the profiles, the ICE-Pro was deployed through auger holes that had been drilled at distances of 82 and $113 \mathrm{~m}$ from the tent and cleaned of ice chunks. Once the ICE-Pro was underneath the ice layer, fresh clean snow was shoveled back into the hole to avoid, as much as possible, having a bright spot above the sensors (see Fig. B1 and Table B1). The frame was then manually lowered at a rate of approximately $0.3 \mathrm{~m} \mathrm{~s}^{-1}$. The above-surface reference sensor was fixed on a steady tripod installed approximately $2 \mathrm{~m}$ above the ice surface and above all neighboring camp features. Data processing and validation were performed using a protocol inspired by that of Smith and Baker (1984), which is now used by several space agencies for their Ocean Color algorithm validation activities. Measurements were taken between 380 and $875 \mathrm{~nm}$ at 19 discrete spectral wavebands. Vertical profiles were usually performed in duplicates or triplicates. Time series of daily photosynthetically active radiation (PAR, computed from the 19 spectral irradiance wavelengths) at the sea-ice-water interface (1.3 m depth) are shown in Fig. 5. In 2016, PAR started to increase rapidly in the second week of May, compared to early June in 2015 . Overall, PAR at $1.3 \mathrm{~m}$ in the water column was also greater in 2016 than in 2015 and reached the threshold of $0.415 \mathrm{~mol}$ of photons $\mathrm{m}^{-2} \mathrm{~d}^{-1}$, above which light is sufficient for net growth (Letelier et al., 2004), a few days earlier. Further information about in situ underwater irradiance and radiance measurements can be found in Massicotte et al. (2018).

\subsubsection{Underwater photos and videos of the ice bottom}

Several vertical profiles up to $30 \mathrm{~m}$ were performed using a GoPro Hero 4 camera mounted on the ICE-Pro and pointing upwards towards the ice bottom (see Fig. B1 and Table B1). 
(a)

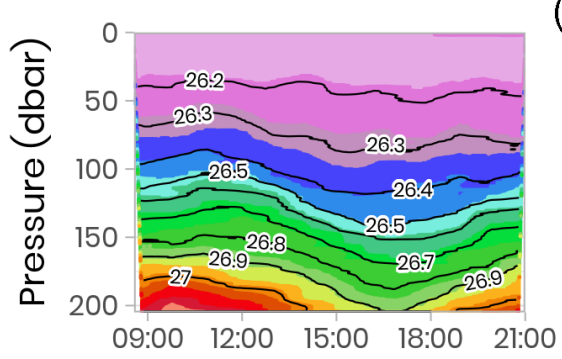

(b)

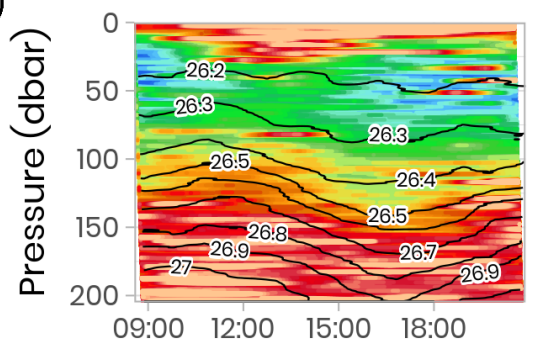

(c)

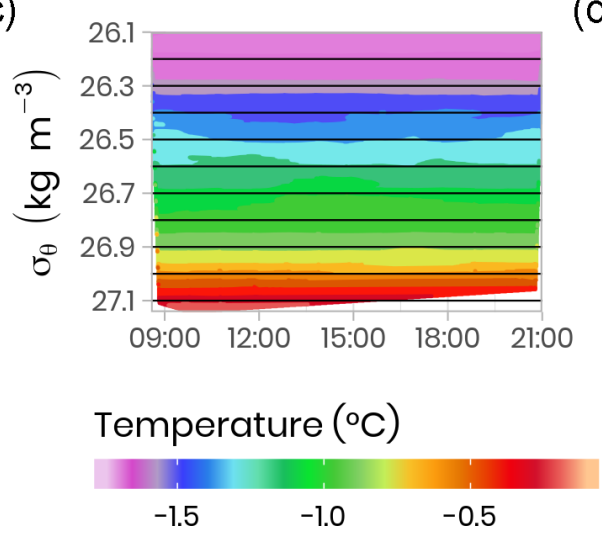

(d)

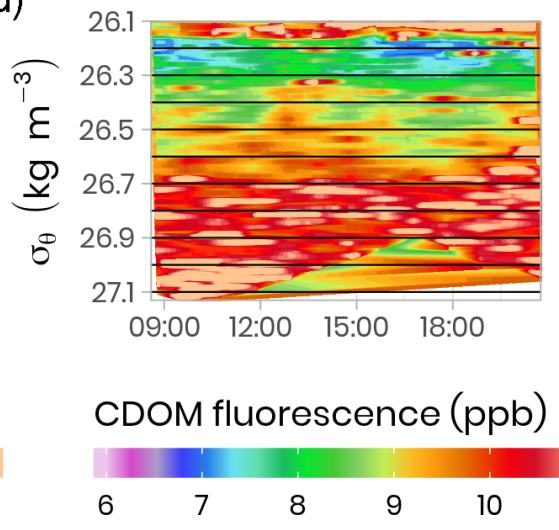

Figure 4. Temporal evolution of physical (temperature) and bio-optical (CDOM fluorescence) variables with superimposed lines of potential density anomaly $\left(\sigma_{\theta}, \mathrm{kg} \mathrm{m}^{-3}\right)$ during a $13 \mathrm{~h}$ tidal cycle. Surface tidal height vs. time at Qikiqtarjuaq is shown in blue. (a, b) Plotted vs. pressure coordinates (equivalent to depth in meters). (c, d) The same data plotted vs. potential density anomaly $\sigma_{\theta} \mathrm{coordinates}\left(\mathrm{kg} \mathrm{m}^{-3}\right.$ ). The tidal survey was performed on 9 June 2015.

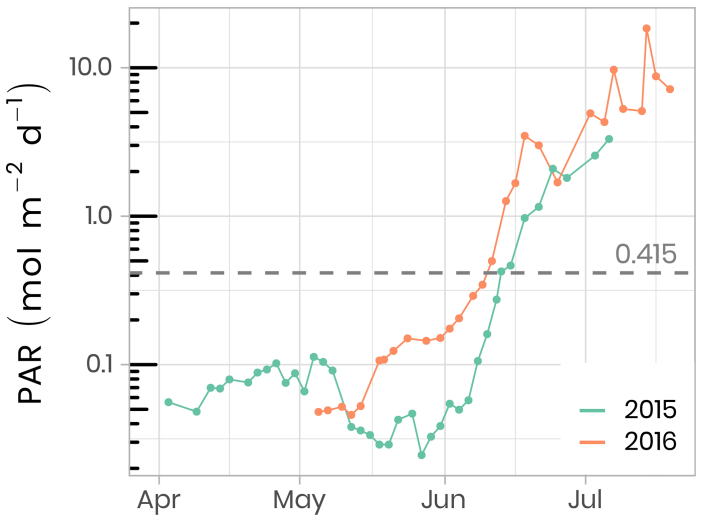

Figure 5. Temporal evolution of daily photosynthetically available radiation (PAR) at the sea-ice-water interface ( $1.3 \mathrm{~m}$ depth) for both ice camp missions. The dashed horizontal line shows the 0.415 mol photons $\mathrm{m}^{-2} \mathrm{~d}^{-1}$ threshold often used in the literature as the minimum light requirement for primary production.

Still images were captured every $5 \mathrm{~s}$ during the descent, and a video was taken of the complete descent. These photos and videos were used for a qualitative assessment of the pronounced spatial and temporal heterogeneity of the under-ice environment and the associated water column nekton community between the two profiling locations.

\subsubsection{Irradiance measurements with TriOS}

To quantify the impact of the heterogeneous radiation field under sea ice on irradiance measurements, replicated spectral irradiance profiles were collected beneath landfast sea ice from 5 May to 8 June 2015 and from 14 June to 4 July 2016. The replicates were made on each sampling day, under different surface conditions. In 2015, measurements were performed prior to melt onset, under different snow depths. In 2016, measurements began after the onset of snowmelt and were performed beneath sea ice with a wet snow cover, shallow melt ponds and white ice. The deployed sensor array consisted of a surface reference radiometer, which recorded incident downwelling planar irradiance, $E_{\mathrm{d}}(0, \phi)$, and three radiometers attached to a custom-built doublehinged aluminum pole (under-ice $\mathrm{L}$-arm) to measure downwelling planar irradiance, $E_{\mathrm{d}}(z, \phi)$, downwelling scalar irradiance, $\stackrel{\circ}{E}_{\mathrm{d}}(z, \phi)$, and upwelling scalar irradiance, $\stackrel{\circ}{\mathrm{u}}_{\mathrm{u}}(z, \phi)$. These four hyperspectral radiometers (two planar RAMSESACC and two scalar RAMSES-ASC, TriOS GmbH, Germany) measured pressure and tilt internally and recorded irradiance spectra in the wavelength range from 320 to $950 \mathrm{~nm}$ at a resolution of $3.3 \mathrm{~nm}$ (190 channels). Transmitted irradiance was recorded along with vertical profiles by lowering the L-arm manually through a $20 \mathrm{~cm}$ auger hole with a winch and $1.5 \mathrm{~m}$ aluminum poles extensions. In 2015, 17 vertical 
(a)
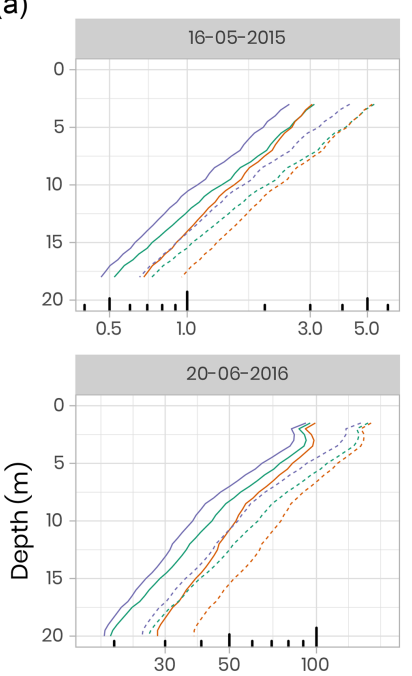

04-07-2016

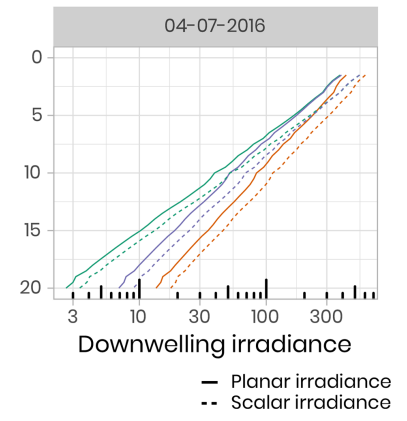

(b)
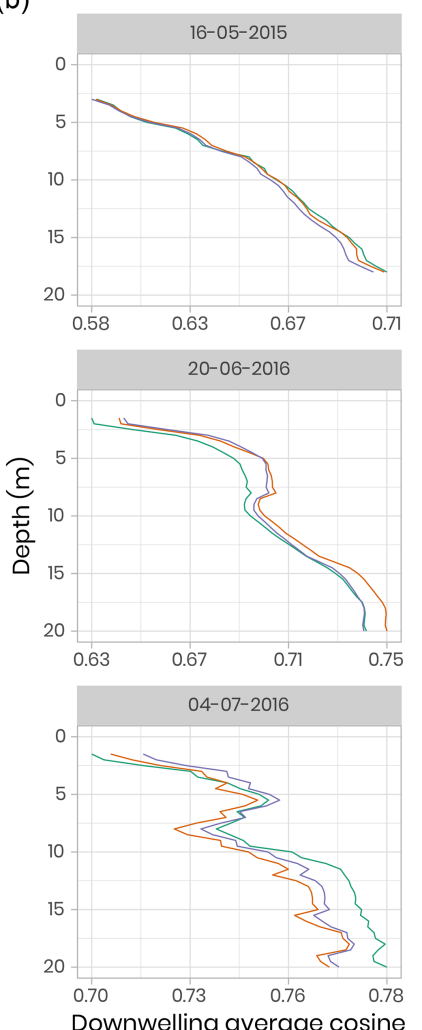

Downwelling average cosine

$-442 \mathrm{~nm}\left(\mathrm{~mW} \mathrm{~m}^{-2} \mathrm{~nm}^{-1}\right)$

- $532 \mathrm{~nm}\left(\mathrm{~mW} \mathrm{~m}^{-2} \mathrm{~nm}^{-1}\right)$

- PAR $\left(\mu \mathrm{mol} \mathrm{m} \mathrm{m}^{-2} \mathrm{~s}^{-1}\right)$

Figure 6. (a) Under-ice vertical profiles of downwelling planar and scalar irradiance at $442 \mathrm{~nm}$ and $532 \mathrm{~nm}$ and for PAR. Note the log scale for the irradiance measurements. (b) Calculated downwelling average cosine (unitless) was measured beneath snow-covered sea ice on 16 May 2015, beneath bare ice on 20 June 2016 and beneath a melt pond on 4 July 2016.

profiles were collected in $0.4-0.5 \mathrm{~m}$ depth steps from the ice bottom to a water depth of $18 \mathrm{~m}$. In 2016, 11 profiles were recorded to a depth of $20 \mathrm{~m}$ under different sea-ice surface conditions. Differences between planar and scalar PAR measurements were used to derive the downwelling average cosine, $\mu \mathrm{d}$, an index of the angular structure of the downwelling under-ice radiation field which, in practice, can be used to convert between downwelling scalar, $\stackrel{\circ}{\mathrm{d}}_{\mathrm{d}}$, and planar, $E_{\mathrm{d}}$, irradiance. The average cosine was smaller prior to snowmelt in 2015 compared to after snowmelt $(\approx 0.6$ vs. 0.7$)$, when melt ponds covered the ice surface in 2016 (Fig. 6). Further details about the sampling procedure, data processing and results can be found in Matthes et al. (2019).

\subsubsection{Inherent optical properties (IOPs)}

IOP measurements were made using an optical frame equipped with the physical and bio-optical sensors that were

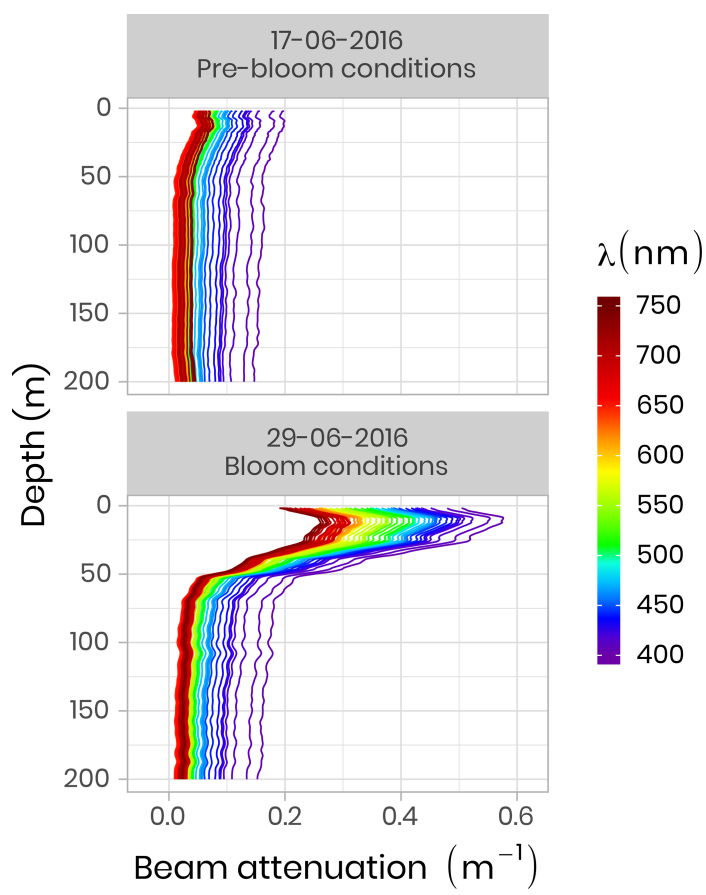

Figure 7. Beam attenuation coefficients $\left(c, \mathrm{~m}^{-1}\right)$ measured in 2016 using a WetLabs AC-S before and during the phytoplankton bloom. Note that the colors of the lines correspond to wavelength frequencies.

factory-calibrated before each field campaign. A Seabird SBE-9 CTD measured temperature, absolute salinity and pressure. A WetLabs AC-S was used for spectral beam attenuation $\left(c, \mathrm{~m}^{-1}\right)$ and total absorption $\left(a, \mathrm{~m}^{-1}\right)$ between 405 and $740 \mathrm{~nm}$, and a BB9 (WetLabs) and BB3 (WetLabs) were utilized for backscattering coefficients $\left(b, \mathrm{~m}^{-1}\right)$ between 440 and $870 \mathrm{~nm}$. During both campaigns, pure water calibration was performed for the AC-S sensor on each sampling day and linear regression of these calibration values as a function of time was computed for each wavelength of absorption and attenuation signals. Following from this, the offset applied during the data processing was taken on this linear regression at the exact date of the measurement. Figure 7 shows two vertical profiles of attenuation coefficients at different wavelengths acquired during pre-bloom and bloom conditions in 2016. One can see that during the bloom, attenuation increased markedly in the $0-50 \mathrm{~m}$ surface layer due to higher phytoplankton biomass.

\subsubsection{Other optical measurements}

Other optical variables measured during both field campaigns included absorbance of particulate matter, absorbance of dissolved organic matter, snow and sea-ice transmittance, snow and ice hyperspectral and hyper-angular hemispherical directional reflectance (Goyens et al., 2018), and surface spectral albedo (Verin et al., 2019) (Table 2). Downwelling 
spectral irradiance above the surface $\left(1^{\circ} \times 1^{\circ}\right.$ spatial resolution, daily temporal resolution, interpolated hourly) was also computed based on the radiative transfer model SBDART (Ricchiazzi et al., 1998), as described in Laliberté et al. (2016) and Randelhoff et al. (2019).

\subsection{Nutrients and carbon compounds}

Nitrate, nitrite, phosphate and silicate concentrations were measured from water filtered through $0.7 \mu \mathrm{m}$ Whatman GF/F filters and through $0.2 \mu \mathrm{m}$ cellulose acetate membranes. Filtrates were collected into sterile $20 \mathrm{~mL}$ polyethylene vials, poisoned with $100 \mu \mathrm{L}$ of mercuric chloride $\left(60 \mathrm{mg} \mathrm{L}^{-1}\right)$ and subsequently stored in the dark prior to analysis. Nutrient concentrations were determined using an automated colorimetric procedure described in Aminot and Kérouel (2007). Figure 8 shows an overview of the dynamics of nitrate, which is often the limiting nutrient for phytoplankton growth in the ocean (Tremblay and Gagnon, 2009). It can be seen that the depletion of the nitrate started in approximately mid-June for both years, coinciding with the initiation of the phytoplankton bloom. However, the depletion was observed deeper in the water column in 2016 compared to 2015 due to stronger currents and a longer sampling period in 2016 (Oziel et al., 2019). Dissolved organic and inorganic carbon (DOC and DIC, respectively), particulate organic and inorganic carbon (POC and PIC, respectively), total organic carbon (TOC), phosphate $\left(\mathrm{PO}_{4}\right)$, orthosilicic acid $\left(\mathrm{Si}(\mathrm{OH})_{4}\right)$, and ammonium $\left(\mathrm{NH}_{4}\right)$, were also measured during both campaigns (Table 2). Detailed information about analytical procedures can be found in the LEFE-CYBER online repository. A comprehensive discussion about nutrient dynamics during the Green Edge missions can be found in Grondin et al. (2019).

\subsection{Bacteria and phytoplankton}

\subsubsection{Flow cytometry}

The abundances of picophytoplankton, nanophytoplankton and bacteria were measured by flow cytometry. Samples $(1.5 \mathrm{~mL})$ were preserved with a mix of glutaraldehyde and Pluronic F-68 (Gibco) (Marie et al., 2014) and frozen at $-80^{\circ} \mathrm{C}$. Samples were analyzed on a FACS Canto flow cytometer (Becton Dickinson) in the laboratory at the Station Biologique de Roscoff. The abundance (cells per milliliter) of phytoplankton populations was determined on unstained samples, and cells were discriminated by their red chlorophyll autofluorescence. Bacterial abundance was determined based on the fluorescence of SYBR green-stained DNA (Marie et al., 1997). In both 2015 and 2016, bacteria concentrations were initially low, on the order of 100000 cells per milliliter, and quite uniform throughout the water column. During the bloom, bacterial abundance increased continuously, reaching values of 1 million cells per milliliter (Fig. 9). Simultaneously, the distribution of highest abundance became stratified with a higher concentration found near the

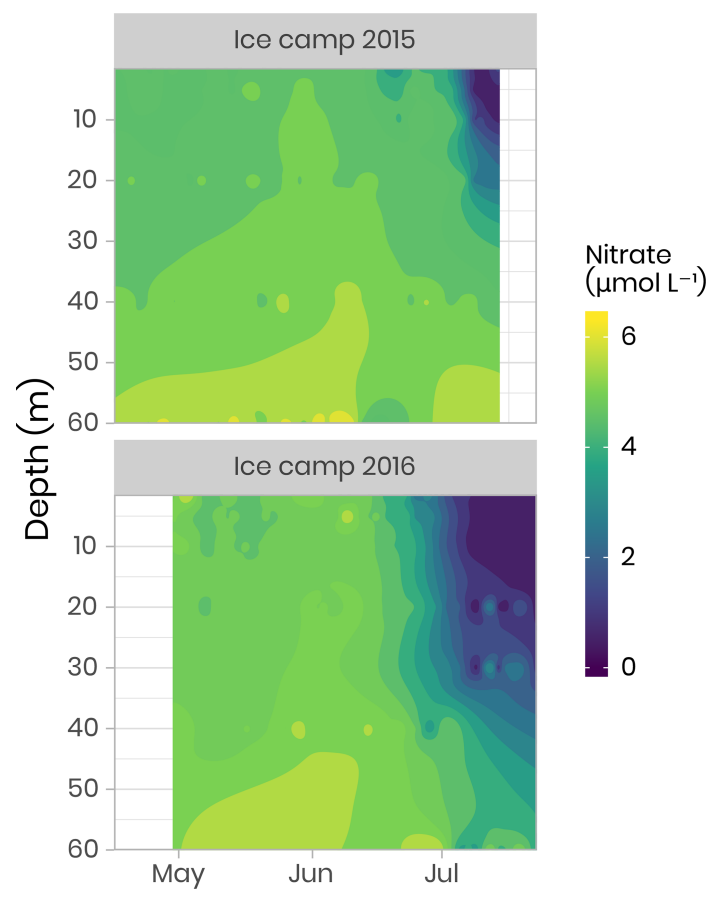

Figure 8. Temporal evolution of nitrate concentrations in the first $60 \mathrm{~m}$ of the water column for both ice camp missions.

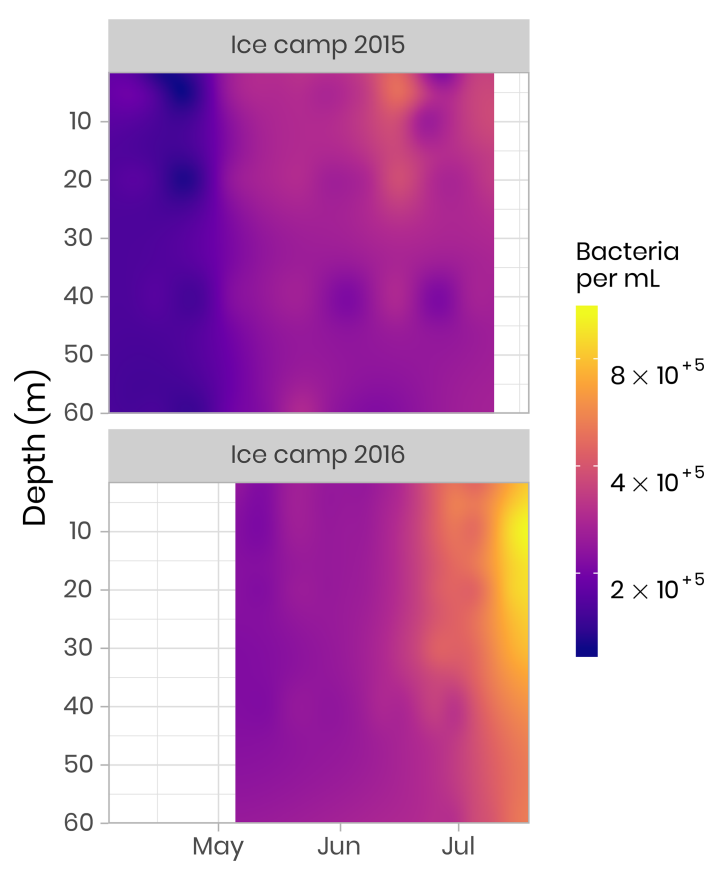

Figure 9. Concentration of bacteria in the water column at the ice camp in 2015 and 2016.

surface in early July before it moved down to the subsurface (between 10 and 20 m) later in July (Fig. 9). In 2015, the sampling period did not extend long enough to capture the full progression of bacterial community development. 


\subsection{Phytoplankton}

\subsubsection{Chlorophyll a}

Chl $a$ and accessory pigments concentrations were determined by high-performance liquid chromatography (HPLC) following Ras et al. (2008). Concentrations were measured using volumes between 0.1 and $1 \mathrm{~L}$ of melted ice and volumes between 1 and $2.5 \mathrm{~L}$ of seawater. Water was filtered onto Whatman GF/F $25 \mathrm{~mm}$ filters and stored at $-80^{\circ} \mathrm{C}$ until analysis. Filters were extracted in $100 \%$ methanol, disrupted by sonication and clarified by filtration. Pigments were analyzed using an Agilent Technologies 1200 Series system with a narrow reversed-phase C8 Zorbax Eclipse XDB column $(150 \times 3 \mathrm{~mm}, 3.5 \mu \mathrm{m}$ particle size $)$, which was maintained at $60^{\circ} \mathrm{C}$. Figure 10 shows the temporal evolution of surface integrated chl $a$ in the bottom $10 \mathrm{~cm}$ of the ice cover and the water column for both years. At the beginning of the sampling periods in 2015 and 2016, total chl $a$ concentrations in the bottom of the ice and the water column were of approximately the same magnitude $\left(\approx 5 \mathrm{mg} \mathrm{m}^{-2}\right)$. Later in the season, when the snowpack and the ice sheet started to melt (between June and July) and at the onset of the PSB, chl $a$ in the water column increased rapidly to reach concentrations of $145 \mathrm{mg} \mathrm{m}^{-2}$ in 2015 and $113 \mathrm{mg} \mathrm{m}^{-2}$ in 2016 . At the same time, or slightly before, chl $a$ in the ice bottom started to decrease rapidly to concentrations varying between 0.1 and $0.3 \mathrm{mg} \mathrm{m}^{-2}$.

Primary production during the phytoplankton bloom was incompletely sampled in 2015, while in 2016 it was monitored from the onset under melting sea ice in May to its termination in July (Fig. 11). Briefly, rates of carbon fixation (primary production), were measured using a dual ${ }^{13} \mathrm{C}-{ }^{15} \mathrm{~N}$ isotopic technique (Raimbault et al., 1999). Water samples and melted ice was collected into three $600 \mathrm{~mL}$ polycarbonate bottles, previously rinsed with $10 \% \mathrm{HCl}$ and then with ultrapure Milli-Q water. Labeled ${ }^{13} \mathrm{C}$ sodium bicarbonate $\left(\mathrm{NaH}^{13} \mathrm{CO}_{3}-6 \mathrm{~g}, 250 \mathrm{~mL}^{-1}\right.$ deionized water -99 at \% ${ }^{13} \mathrm{C}$, EURISOTOP) was added to each bottle in order to obtain $\approx 9.7 \%$ final enrichment $(0.5 \mathrm{~mL}$ per $580 \mathrm{~mL}$ of seawater). After the addition of ${ }^{13} \mathrm{C}$-tracer $\left(\mathrm{H}^{13} \mathrm{CO}_{3}\right)$, samples were spiked with inorganic nitrogen labeled with ${ }^{15} \mathrm{~N}$. Immediately after tracer addition, samples were fixed on an array placed under the ice. Incubation was stopped after $24 \mathrm{~h}$ and samples were immediately filtered on Whatman GF/F filters ( $25 \mathrm{~mm}$ diameter) precombusted at $500^{\circ} \mathrm{C}$. These filters were used to determine the final ${ }^{15} \mathrm{~N} /{ }^{13} \mathrm{C}$ enrichment ratio in the particulate organic matter and the concentrations of particulate carbon and particulate nitrogen. During the ice-covered period in 2015, primary production, as well as nitrate assimilation $\left(\mathrm{rNO}_{3}\right)$, occurred at very low but detectable rates reaching 8 and $0.4 \mathrm{mmol} \mathrm{m}^{-2} \mathrm{~d}^{-1}$, respectively. Phytoplankton production rates were higher in the ice than in the water column, representing approximately $80 \%$ and $40 \%$ for primary production and $\mathrm{rNO}_{3}$, respectively. Estimated assim-

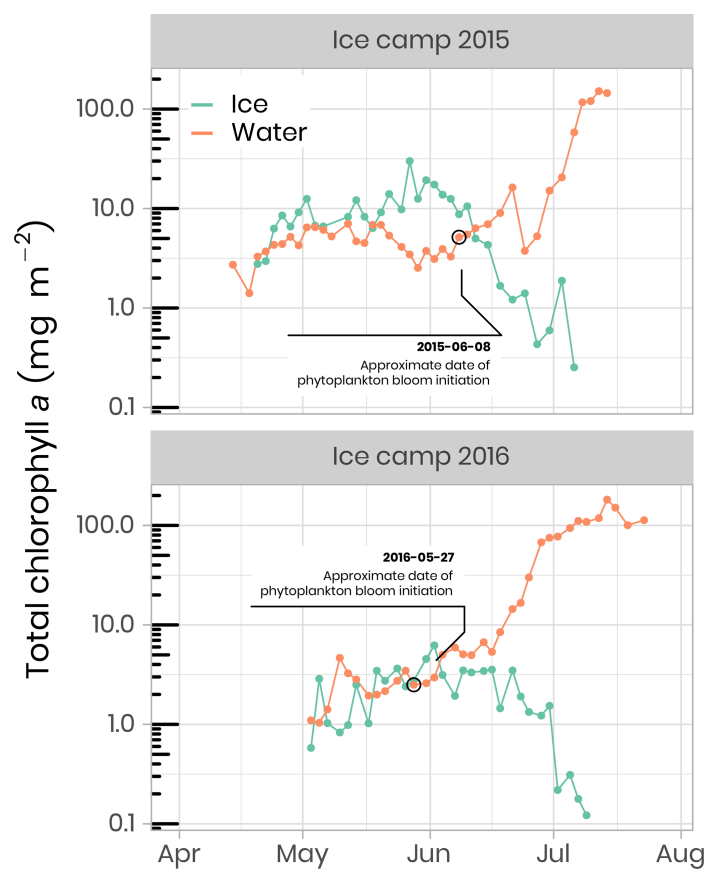

Figure 10. Temporal evolution of chlorophyll $a$ in ice and water (depth-integrated) for both ice camp missions. Note that the water chlorophyll $a$ have been integrated over the first $100 \mathrm{~m}$ of the water column, whereas the ice chlorophyll $a$ was measured on the bottom $0-10 \mathrm{~cm}$ of the ice cores. The details of the calculations to determine the approximate dates of phytoplankton bloom initiation can be found in Oziel et al. (2019).

ilated concentrations of total carbon and nitrate within the ice cover were $30-96$ and $1.4-4.6 \mathrm{mmol} \mathrm{m}^{-2}$ during this period. The break-up of the sea-ice cover was characterized by a rapid increase in primary production and $\mathrm{rNO}_{3}$. During this period of high light transmission through the melting ice cover (day 169 to 190), concentrations of assimilated total carbon and $\mathrm{rNO}_{3}$ reached 60 and $8 \mathrm{mmol} \mathrm{m}^{-2}$, respectively, leading to a complete nitrate depletion. The quantities of total carbon and nitrate assimilated during the 2016 PSB in the water column were 562 and $97 \mathrm{mmol} \mathrm{m}^{-2}$, respectively.

\subsubsection{Phytoplankton taxonomy}

The phytoplankton community species composition was determined using an Imaging FlowCytobot (IFCB, Woods Hole Oceanographic Institute, Sosik and Olson, 2007; Olson and Sosik, 2007). The size range targeted was between 1 and $150 \mu \mathrm{m}$, while the image resolution of approximately 3.4 pixels $\mu \mathrm{m}^{-1}$ limited the identification of cell $<10 \mu \mathrm{m}$ to broad functional groups. A $150 \mu \mathrm{m}$ Nitex mesh was used to avoid clogging of the fluidics system by large particles, although this might have induced a bias in the results by preventing large cells to be sampled. For each melted ice and seawater sample, $5 \mathrm{~mL}$ was analyzed and Milli-Q water was run between samples with high biomass in order 


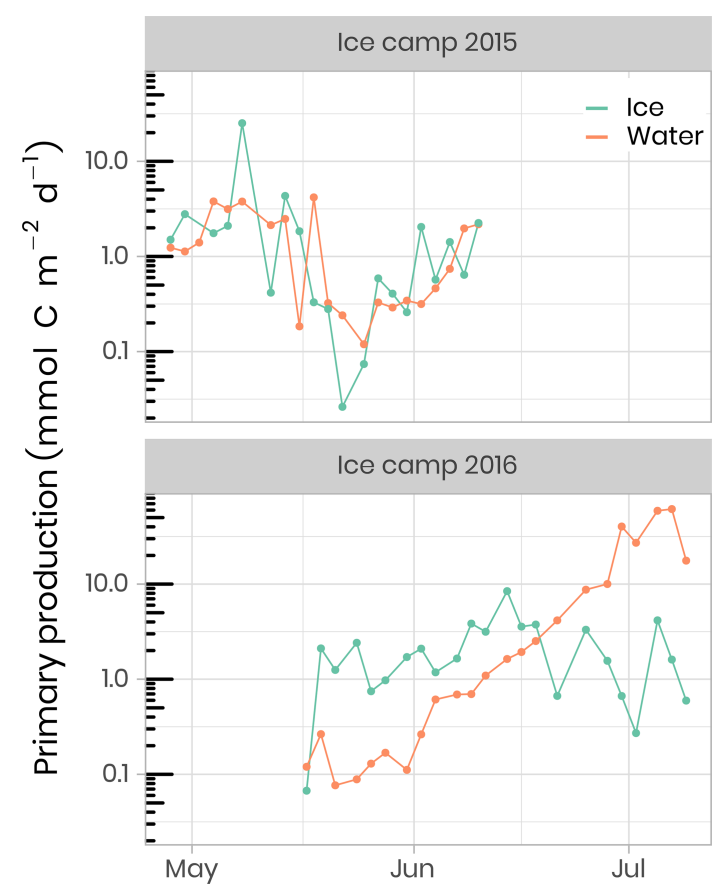

Figure 11. Temporal evolution of primary production in ice and water (depth-integrated) for both ice camp missions.

to prevent contamination between samples. Image acquisition was triggered by chl $a$ in vivo fluorescence, with excitation and emission wavelengths of 635 and $680 \mathrm{~nm}$, respectively. Grayscale images were processed to extract regions of interest (ROIs) and their associated features (e.g., geometry, shape, symmetry, texture, etc.), using a custom made MATLAB (2013b) code (Sosik and Olson, 2007; Olson and Sosik, 2007; processing codes are available at https://github.com/hsosik/ifcb-analysis, last access: 2 December 2019). A total of 231 features (see the full list and description at https://github.com/hsosik/ifcb-analysis/wiki/ feature-file-documentation, last access: 2 December 2019) were derived on the resulting ROIs and were used for automatic classification using random forest algorithms with the EcoTaxa application (Picheral et al., 2017). A learning set was manually prepared for each year, with ca. 20000 images annotated and used for automatic prediction. Each automatically annotated image was further validated by visual examination and corrected when necessary. The final 2015 and 2016 datasets consist of 124247 and 57397 annotated images and their associated features in 39 and 35 taxonomic categories, respectively (Fig. 12). As it was impossible to count the number of cells in each image, we assumed one cell per image. To account for potential underestimations of cell abundance when colonies or chains were imaged, the biovolume of each living protist in the images was computed during image processing according to Moberg and Sosik (2012). Using carbon to volume ratios from Menden-Deuer and Lessard (2000), biovolume was converted into carbon estimates, as

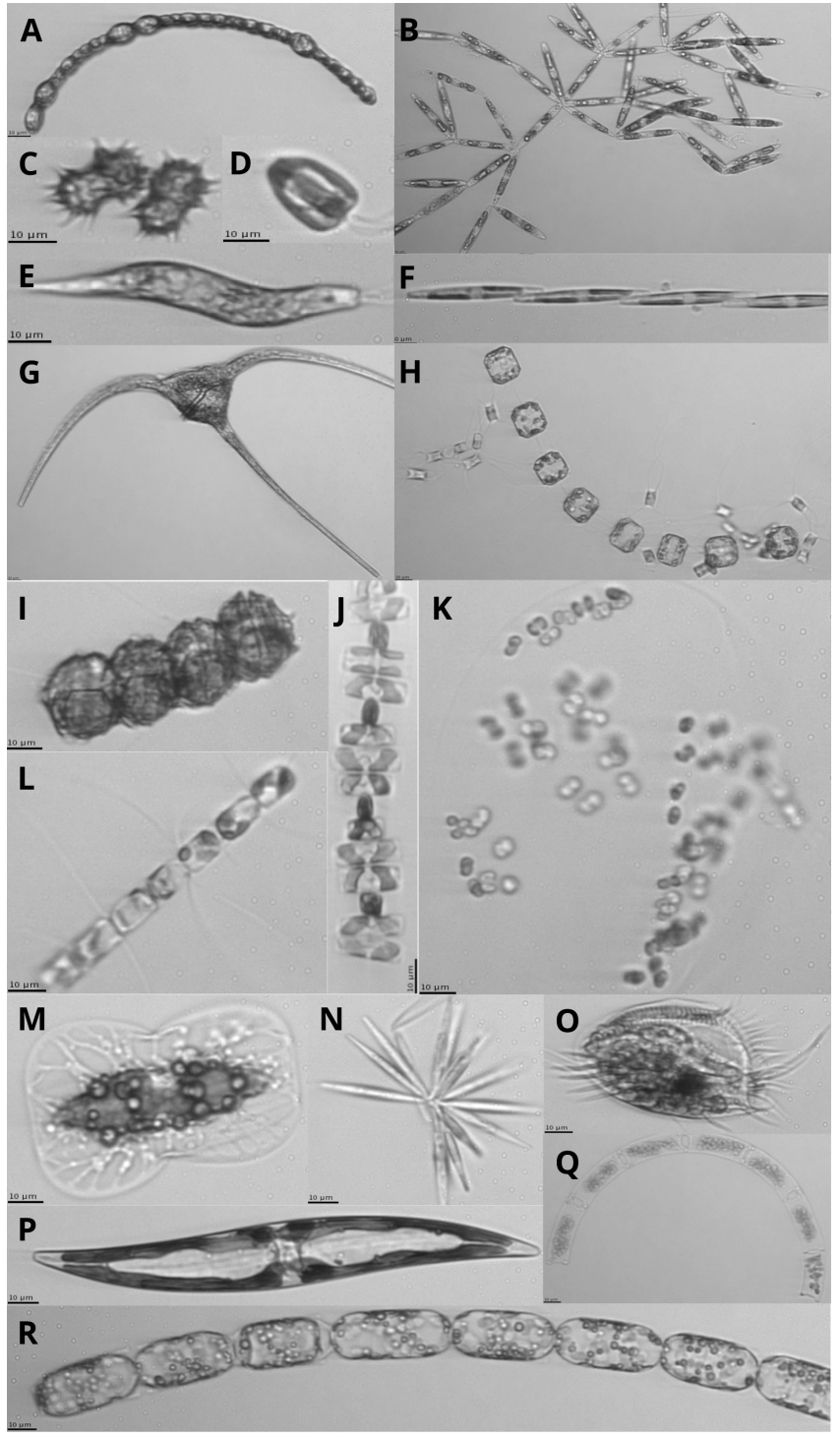

Figure 12. Images of protists sampled with the IFCB (scale bar on images is $10 \mu \mathrm{m}$; note that the images are not to scale): (a) $A n$ abaena sp., (b) Nitzschia frigida, (c) Polarella glacialis, (d) Flagellate, (e) Euglena, (f) Pseudo-nitzschia sp., (g) Ceratium sp., (h) Thalassiosira nordenskioeldii with Attheya septentrionalis, (i) Peridiniella catenata, (j) Navicula pelagica, (k) Phaeocystis sp. colony, (l) Chaetoceros sp., (m) Entomoneis sp., (n) Synedropsis hyperborea, (o) Ciliate, (p) Pennate diatom, (q) Eucampia sp., and (r) Melosira sp. 
described in Laney and Sosik (2014). Detailed information about sea-ice algae and phytoplankton community composition can be found in Grondin et al. (2019).

\subsubsection{Physiology of the phytoplankton community}

The photosynthetic potential of microalgae was assessed by measuring $F_{v} / F_{\mathrm{m}}$, namely the maximum photochemical efficiency of Photosystem II (PSII), via dynamic chl $a$ fluorescence:

$\frac{F_{v}}{F_{\mathrm{m}}}=\frac{\left(F_{\mathrm{m}}-F_{0}\right)}{F_{\mathrm{m}}}$,

where $F_{\mathrm{m}}$ and $F_{0}$ are the maximum and minimum PSII chl $a$ fluorescence yields, respectively. Chl $a$ fluorescence was recorded with a WATER-PAM fluorometer (Heinz Walz $\mathrm{GmbH}$, Germany) on melted sea-ice (last centimeter of the cores) and water samples collected at different depths (i.e., $1.5,10,40,60 \mathrm{~m})$. Measurements were performed after storing samples in $50 \mathrm{~mL}$ dark Falcon tubes (Corning Life Sciences, USA) on ice for at least $1 \mathrm{~h}$. For further technical details, see Galindo et al. (2017). $F_{v} / F_{\mathrm{m}}$ is often used as an index for evaluating the physiological condition of microalgal communities. For algae that are growing optimally, the $F_{v} / F_{\mathrm{m}}$ ratio ranges between 0.50 and 0.75 in the absence of cyanobacteria. Below 0.50, algal growth is considered to be limited by nutrient availability and/or light stress (Suggett et al., 2010). Figure 13 shows the temporal evolution of $F_{v} / F_{\mathrm{m}}$ for ice algae and phytoplankton for the ice camp in 2016. At the beginning of the sampling period, all samples showed $F_{v} / F_{\mathrm{m}}$ above 0.55 . While in ice $F_{v} / F_{\mathrm{m}}$ ranged between 0.60 and 0.75 until the beginning of June, when it decreased to ca. $0.20-0.35$ in water. This decrease in $F_{v} / F_{\mathrm{m}}$ (Fig. 13a) is coincident with a sharp increase in PAR under the ice sheet (Fig. 5), which may have induced light stress in phytoplankton and ice algae communities. After approximately 1 month, phytoplankton became acclimated to this new light environment and $F_{v} / F_{\mathrm{m}}$ increased back to 0.60 0.75 by the beginning of June. From that time on (corresponding to higher irradiance transmittance through ice; see Fig. 5), $F_{v} / F_{\mathrm{m}}$ in ice decreased dramatically to an approximate value of 0.20 , while $F_{v} / F_{\mathrm{m}}$ in the water column generally remained between 0.60 and 0.75 for depths between 10 and $60 \mathrm{~m}$ (note, however, the large decrease at $40 \mathrm{~m}$ on 13 June). In contrast, $F_{v} / F_{\mathrm{m}}$ at $1.5 \mathrm{~m}$ was lower and noisier with values varying between 0.45 and 0.60 .

In addition to the photosynthetic potential of microalgae, photosynthetic parameters were measured from seawater incubated at different irradiance levels in the presence of ${ }^{14} \mathrm{C}$ labeled sodium bicarbonate. The light saturation parameter, $E_{k}$, is an indication of the light acclimation state of the phytoplankton community. Figure $13 \mathrm{~b}$ shows the increase in $E_{k}$ as the phytoplankton community grows between May and July 2016 at 1.5, 5 and $10 \mathrm{~m}$ depth. Between 1.5 and $10 \mathrm{~m}$ depth, $E_{k}$ varied between 15 and $194 \mu \mathrm{mol} \mathrm{m}^{-2} \mathrm{~s}^{-1}$ (a)

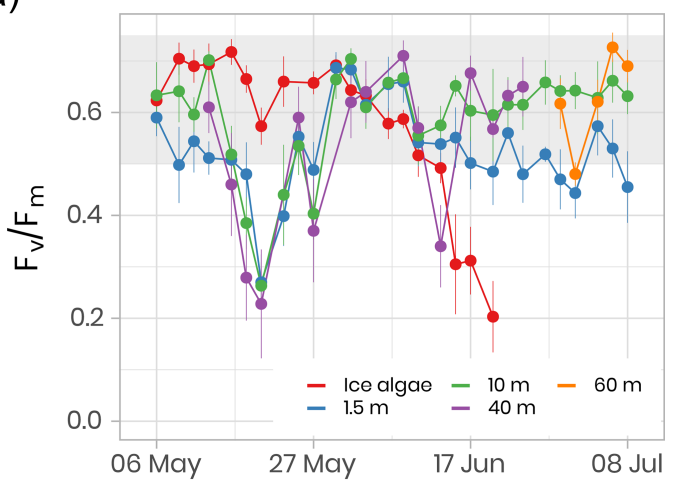

(b)

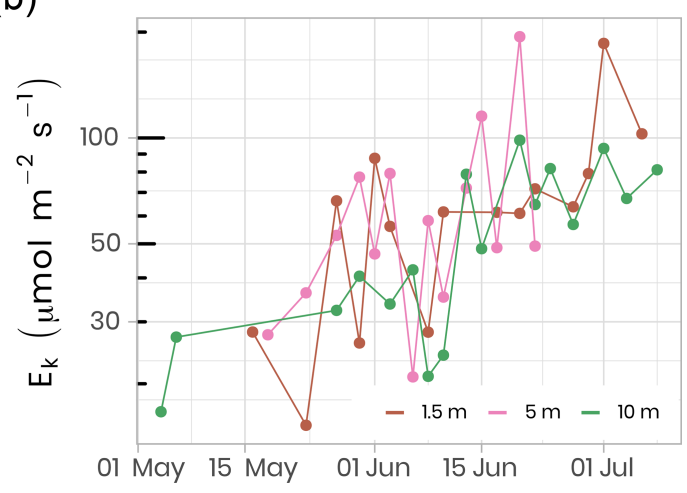

Figure 13. (a) Temporal evolution of $F_{v} / F_{\mathrm{m}}$ for ice (last $\mathrm{cm}$ ) and water underneath the ice (depths 1.5, 10, $40 \mathrm{~m}$ ) samples for the ice camp 2016 between 6 May and 8 July. $F_{v} / F_{\mathrm{m}}$ monitoring on ice samples stopped on 20 June because the chl $a$ fluorescence signal was not reliable anymore. $F_{v} / F_{\mathrm{m}}$ monitoring on 40 and $60 \mathrm{~m}$ depth samples was limited between 13 May and 24 June and between 29 June and 8 July, respectively. The gray shaded area represents the range at which the algae are optimally growing. (b) The light saturation parameter, $E_{k}$, an index of photo-adaptation of the phytoplankton community, was measured at $1.5,5$ and $10 \mathrm{~m}$ depth. Note the log scale on the $y$ axis.

$\left(61 \pm 37 \mu \mathrm{mol} \mathrm{m}{ }^{-2} \mathrm{~s}^{-1}, n=69\right)$, which falls in a range within the values reported in other marine studies conducted at high latitudes (Bouman et al., 2018; Massicotte et al., 2019b). The observed increase in $E_{k}$ over the growing season suggests that the phytoplankton community became more photoadapted to increasing available irradiance (Fig. 5).

\subsection{Zooplankton}

Zooplankton was collected from a ring net deployed under the ice at the ice camp between 22 April and 10 June in 2015 and between 16 May and 18 July in 2016. This sampler, composed of a $1 \mathrm{~m}$ diameter circular frame mounted with a $4 \mathrm{~m}$ long, $200 \mu \mathrm{m}$ mesh size, conical plankton net was lowered cod end first to avoid filtration during the descent using an electric winch. An additional $50 \mu \mathrm{m}$ net with an aperture of $10 \mathrm{~cm}$ in diameter was attached to the side 


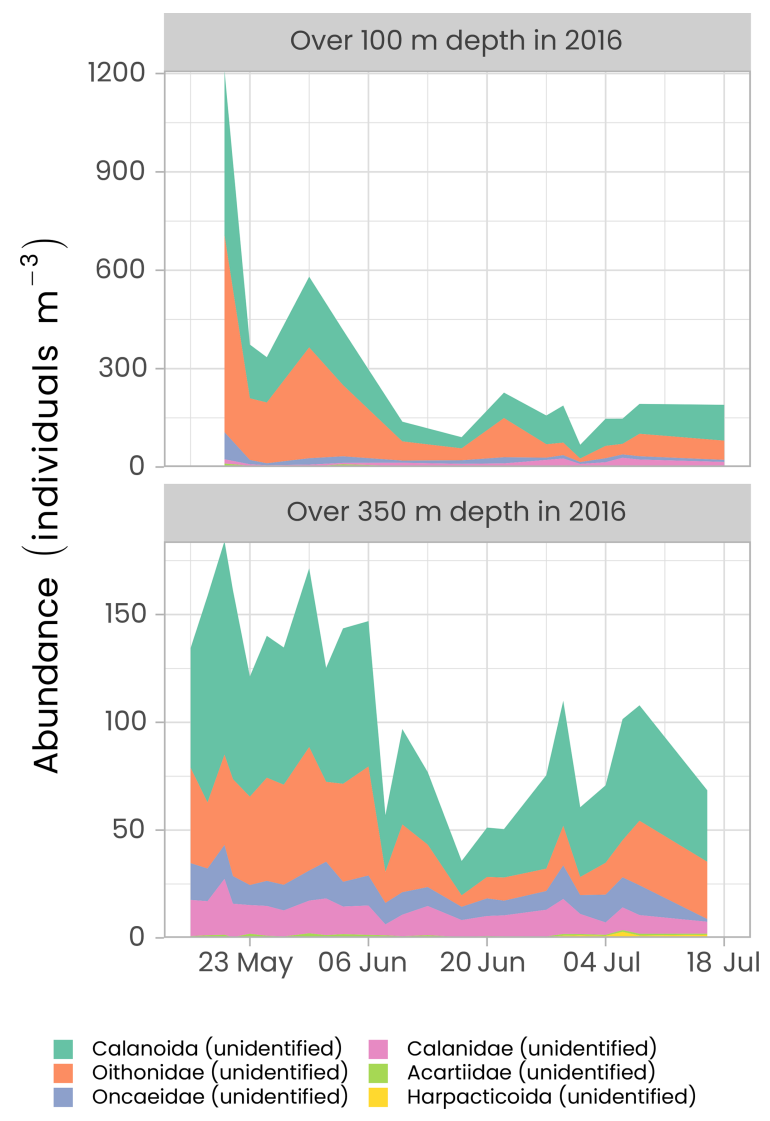

Figure 14. Time series of the abundance of the copepods (individuals per $\mathrm{m}^{-3}$ ) measured over the first 100 and $350 \mathrm{~m}$ of the water column in 2016 using the ZooScan. For visualization, only the six most abundant groups are presented in decreasing order of importance. Note the different $y$ axes in both panels.

of the metal ring to sample eggs and small zooplankton larvae, while the main net collected the mesozooplankton fraction. This sampling device was hauled vertically from a depth of $100 \mathrm{~m}$ (2015 and 2016) or $350 \mathrm{~m}$ (only in 2016), $10 \mathrm{~m}$ above the seafloor to the surface at a speed of about $30 \mathrm{mmin}^{-1}$. The filtered volume was estimated by a $\mathrm{KC}$ Denmark flowmeter placed in the mouth of the $200 \mu \mathrm{m}$ mesh net. Samples were preserved in $10 \%$ buffered formalin seawater solution for further taxonomic analyses. Classification and count of the $200 \mu \mathrm{m}$ mesh net samples from both campaigns were performed using the ZooScan by the PIQv team at l'Observatoire Océanographique de Villefranche-sur-Mer, France, following their protocol. Figure 14 shows the time series of the abundance of copepods (the dominant group of zooplankton in the Arctic) for the first 100 and $350 \mathrm{~m}$ of the water column in 2016.

The highest copepod abundance was observed in late May and early June in both the top $100 \mathrm{~m}$ and over the $350 \mathrm{~m}$ hauling depths. At the beginning of the sampling period, abundance was approximately 10 times higher in the first $100 \mathrm{~m}$ of the water column than over $350 \mathrm{~m}$, suggesting that copepods were agglomerating near the surface to exploit the ice algae production before the start of phytoplankton production. Abundance started to decrease during the first week of June. The family of Oithonidae and the order of Calanoida were the two most abundant groups over the two sampling depths. Oithonidae was more abundant over the top $100 \mathrm{~m}$ layer as this group is probably mainly composed of small epipelagic Oithona similis, one of the most numerous copepods in the Arctic. Calanoida, the most common copepod order, which includes the families Calanidae (including species such as Calanus spp.) and Acartiidae, was the dominant group over the $350 \mathrm{~m}$ depth haul.

\subsection{Other data}

An exhaustive list of all measured variables is presented in Table 2, along with contact information of principal investigators associated with each measured parameter.

\section{Recommendations and lessons learned}

As with any Arctic survey, a large number of measurements were acquired during the Green Edge project. Although initial recommendations on good practices about collection, processing and storage of collected data were communicated to all scientists, extensive efforts, such as data standardization, had to be performed to assemble the data. It is important for reducing possible errors that a uniformized data management plan should be prepared and distributed prior to each mission. Furthermore, dedicated data management specialists should be involved from the beginning of the project to ensure the data are adequately collected, tidied, stored, backed up and archived.

\section{Code and data availability}

The raw data provided by all the researchers, as well as metadata, are available on the LEFE-CYBER repository (http://www.obs-vlfr.fr/proof/php/GREENEDGE/ greenedge.php, last access: 2 December 2019, LEFECYBER, 2019). The data presented in this paper and in Table 2 are hosted at SEANOE (SEA scieNtific Open data Edition) under the CC-BY license (https://www.seanoe.org/ data/00487/59892/, last access: 2 December 2019, Massicotte et al., 2019a). Detailed metadata are associated with each file including the principal investigator's contact information. For specific questions, please contact the principal investigator associated with the data (see Table 2).

\section{Conclusions}

The comprehensive dataset assembled during both Green Edge ice camp campaigns allowed us to study the fundamental physical, chemical and biological processes controlling 
Table 2. Parameters measured during the Green Edge ice camp surveys. Parameters are ordered by alphabetical order and sampling year.

\begin{tabular}{|c|c|c|c|c|}
\hline Year & Parameter & Sampling method & Principal investigators & Processed \\
\hline 2015 & Absorption coefficient & In-water profiler & Guislain Bécu/Marcel Babin & Available \\
\hline 2015 & Absorption (particulate) & Camp ice sample & Jens Ehn/Christine Cox & Available \\
\hline 2015 & Absorption (particulate) & Camp water sample & Jens Ehn/Christine Cox & Available \\
\hline 2015 & Absorption (particulate) & Camp ice sample & Atsushi Matsuoka/ & Available \\
\hline 2015 & Absorption (particulate) & Camp water sample & $\begin{array}{l}\text { Annick Bricaud/Joannie Ferland } \\
\text { Atsushi Matsuoka/ } \\
\text { AnnickBricaud/Joannie Ferland }\end{array}$ & Available \\
\hline 2015 & ADCP (mooring) & Mooring & Claudie Marec & Available \\
\hline 2015 & Aerosol optical depth & Surface mode & $\begin{array}{l}\text { Simon Bélanger/ } \\
\text { Clemence Goyens/ } \\
\text { Edouard Leymarie }\end{array}$ & Available \\
\hline 2015 & Aerosol relative humidity & Surface mode & $\begin{array}{l}\text { Simon Bélanger/ } \\
\text { Clemence Goyens/ } \\
\text { Edouard Leymarie }\end{array}$ & Available \\
\hline 2015 & Air relative humidity & Meteorological tower & Guillaume Massé & Available \\
\hline 2015 & Air temperature & Meteorological tower & Guillaume Massé & Available \\
\hline 2015 & Alkalinity total (TA) & Camp water sample & Brent Else/Jeremy Whitehead & Available \\
\hline 2015 & Ammonium $\left(\mathrm{NH}_{4}^{+}\right)$ & Camp water sample & Patrick Raimbault & $\begin{array}{l}\text { Data not } \\
\text { available yet }\end{array}$ \\
\hline 2015 & Ammonium $\left(\mathrm{NH}_{4}^{+}\right.$, assimilation) & Camp water sample & Patrick Raimbault & Available \\
\hline 2015 & Ammonium $\left(\mathrm{NH}_{4}^{+}\right.$, regeneration) & Camp water sample & Patrick Raimbault & Available \\
\hline 2015 & Angstrom coefficient & Surface mode & $\begin{array}{l}\text { Simon Bélanger/ } \\
\text { Clemence Goyens/ } \\
\text { Edouard Leymarie }\end{array}$ & Available \\
\hline 2015 & Attenuation coefficient & In-water profiler & Guislain Bécu/Marcel Babin & Available \\
\hline 2015 & Backscattering coefficient & In-water profiler & Guislain Bécu/Marcel Babin & Available \\
\hline 2015 & Bacterial sequencing & Air filtration & Rémi Amiraux & Available \\
\hline 2015 & Bacterial sequencing & Camp water sample & Rémi Amiraux & Available \\
\hline 2015 & Bacterial sequencing & Ice core & Rémi Amiraux & Available \\
\hline 2015 & Bacterial sequencing & Sediment trap & Rémi Amiraux & Available \\
\hline 2015 & Brine salinity and volume & Sea-ice core & Virginie Galindo/Søren Rysgaard & Available \\
\hline 2015 & Chlorophyll $a$ & In-water profiler & Guislain Bécu/Marcel Babin & Available \\
\hline 2015 & Chlorophyll $a$ & Sediment trap & Louis Fortier/Catherine Lalande & Available \\
\hline 2015 & $\begin{array}{l}\text { Chlorophyll } a \text { and phaeopigments } \\
\text { (concentration) }\end{array}$ & Camp water sample & Marcel Babin/Joannie Ferland & Available \\
\hline 2015 & $\begin{array}{l}\text { Chlorophyll } a \text { and phaeopigments } \\
\text { (concentration) }\end{array}$ & Camp water sample & Patrick Raimbault & $\begin{array}{l}\text { Data not } \\
\text { available yet }\end{array}$ \\
\hline 2015 & $\begin{array}{l}\text { Chromophoric dissolved organic } \\
\text { matter absorption }\end{array}$ & In-water profiler & Guislain Bécu/Marcel Babin & Available \\
\hline 2015 & $\begin{array}{l}\text { Chromophoric dissolved organic } \\
\text { matter absorption }\end{array}$ & Camp water sample & $\begin{array}{l}\text { Atsushi Matsuoka/ } \\
\text { Joannie Ferland/Marcel Babin }\end{array}$ & Available \\
\hline 2015 & $\begin{array}{l}\text { Conductivity, temperature } \\
\text { and depth (CTD) }\end{array}$ & In-water profiler & Guislain Bécu/Marcel Babin & Available \\
\hline 2015 & $\begin{array}{l}\text { Conductivity, temperature } \\
\text { and depth (CTD) }\end{array}$ & In-water profiler & $\begin{array}{l}\text { Pascal Guillot/ } \\
\text { Marcel Babin/Claudie Marec }\end{array}$ & Available \\
\hline 2015 & Cryptophytes (abundance) & Camp water sample & Daniel Vaulot/Dominique Marie & Available \\
\hline 2015 & Diffuse attenuation coefficient (Kd) & Profile mode & Guislain Bécu/Marcel Babin & Available \\
\hline 2015 & Dimethyl sulfide (DMS) & Camp water sample & Maurice Levasseur & Available \\
\hline 2015 & Dimethyl sulfide (DMS) & Melt pond water sample & Maurice Levasseur & Available \\
\hline 2015 & Dimethyl sulfide (DMS) & Sea-ice core & Maurice Levasseur & Available \\
\hline
\end{tabular}


Table 2. Continued.

\begin{tabular}{|c|c|c|c|c|}
\hline Year & Parameter & Sampling method & Principal investigators & Processed \\
\hline 2015 & $\begin{array}{l}\text { Dimethylsulfoniopropionate } \\
\text { (DMSP) }\end{array}$ & Camp water sample & Maurice Levasseur & Available \\
\hline 2015 & $\begin{array}{l}\text { Dimethylsulfoniopropionate } \\
\text { (DMSP) }\end{array}$ & Melt pond water sample & Maurice Levasseur & Available \\
\hline 2015 & $\begin{array}{l}\text { Dimethylsulfoniopropionate } \\
\text { (DMSP) }\end{array}$ & Sea-ice core & Maurice Levasseur & Available \\
\hline 2015 & Dissolved inorganic carbon (DIC) & Camp water sample & Brent Else/Jeremy Whitehead & Available \\
\hline 2015 & Dissolved organic matter (sugars) & Rosette & $\begin{array}{l}\text { Richard Sempéré/ } \\
\text { Christos Panagiotopoulos }\end{array}$ & Available \\
\hline 2015 & $\begin{array}{l}\text { Dissolved organic nitrogen } \\
\text { (release) }\end{array}$ & Camp water sample & Patrick Raimbault & Available \\
\hline 2015 & Downwelling irradiance & Surface mode & $\begin{array}{l}\text { Simon Bélanger/ } \\
\text { Clemence Goyens/ } \\
\text { Edouard Leymarie }\end{array}$ & Available \\
\hline 2015 & $\begin{array}{l}\text { Downwelling irradiance above the } \\
\text { surface }\left(E_{\mathrm{d}}\left(0^{+}\right)\right)\end{array}$ & Surface mode & Marcel Babin/Martí Galí & Available \\
\hline 2015 & $\begin{array}{l}\text { Downwelling irradiance above the } \\
\text { surface }\left(E_{\mathrm{d}}\left(0^{+}\right)\right)\end{array}$ & Profile mode & Guislain Bécu/Marcel Babin & Available \\
\hline 2015 & Downwelling irradiance $\left(E_{\mathrm{d}}(z)\right)$ & Profile mode & Guislain Bécu/Marcel Babin & Available \\
\hline 2015 & $\begin{array}{l}E_{\mathrm{d}}\left(0^{+}\right) \text {spectra from SBDART } \\
\text { radiative transfer simulations }\end{array}$ & Surface mode & Marcel Babin/Martí Galí & Available \\
\hline 2015 & Fecal pellets flux & Sediment trap & Louis Fortier/Catherine Lalande & Available \\
\hline 2015 & $\begin{array}{l}\text { Hemispherical directional } \\
\text { reflectance distribution function }\end{array}$ & Surface mode & $\begin{array}{l}\text { Simon Bélanger/ } \\
\text { Clemence Goyens/ } \\
\text { Edouard Leymarie }\end{array}$ & Available \\
\hline 2015 & $\begin{array}{l}\text { Hemispherical directional } \\
\text { reflectance factor }\end{array}$ & Surface mode & $\begin{array}{l}\text { Simon Bélanger/ } \\
\text { Clemence Goyens/ } \\
\text { Edouard Leymarie }\end{array}$ & Available \\
\hline 2015 & Heterotrophic bacteria (abundance) & Camp water sample & Daniel Vaulot/Dominique Marie & Available \\
\hline 2015 & Heterotrophic nanoflagellates & Camp water sample & Fabien Joux & Available \\
\hline 2015 & Ice and snow temperature & Meteorological tower & Guillaume Massé & Available \\
\hline 2015 & Ice thickness & Camp ice sample & Virginie Galindo/Søren Rysgaard & Available \\
\hline 2015 & $\begin{array}{l}\text { Irradiance (downwelling, } \\
\text { upwelling) }\end{array}$ & $\begin{array}{l}\text { Surface water and underwater } \\
\text { profile mode }\end{array}$ & $\begin{array}{l}\text { Lisa Matthes/Jens Ehn/ } \\
\text { Simon Lambert-Girard/ } \\
\text { Christopher-John Mundy }\end{array}$ & Available \\
\hline 2015 & Isoprenoid lipids & Camp water sample & $\begin{array}{l}\text { Guillaume Massé/ } \\
\text { Caroline Guilmette }\end{array}$ & Available \\
\hline 2015 & Isoprenoid lipids & Sea-ice core & $\begin{array}{l}\text { Guillaume Massé/ } \\
\text { Caroline Guilmette }\end{array}$ & Available \\
\hline 2015 & Net radiation & Surface mode & Brent Else & Available \\
\hline 2015 & Nitrate $\left(\mathrm{NO}_{3}^{-}\right)$ & Camp water sample & Patrick Raimbault & Available \\
\hline 2015 & Nitrate $\left(\mathrm{NO}_{3}^{-}\right)$ & Sea-ice core & Patrick Raimbault & Available \\
\hline 2015 & Nitrate $\left(\mathrm{NO}_{3}^{-}\right.$, assimilation $)$ & Camp water sample & Patrick Raimbault & Available \\
\hline 2015 & Nitrification & Camp water sample & Patrick Raimbault & Available \\
\hline 2015 & Nitrite $\left(\mathrm{NO}_{2}^{-}\right)$ & Camp water sample & Patrick Raimbault & Available \\
\hline 2015 & Nitrite $\left(\mathrm{NO}_{2}^{-}\right)$ & Sea-ice core & Patrick Raimbault & Available \\
\hline 2015 & $\begin{array}{l}\text { PAR from SBDART radiative } \\
\text { transfer simulations }\end{array}$ & Surface mode & Marcel Babin/Martí Galí & Available \\
\hline 2015 & Particle size distribution & In-water profiler & Guislain Bécu/Marcel Babin & Available \\
\hline 2015 & Particles size & $\begin{array}{l}\text { Underwater vision profiler } \\
\text { (UVP) }\end{array}$ & Claudie Marec/Marc Picheral & Available \\
\hline 2015 & Particulate carbon (PC) & Camp water sample & Marcel Babin/Joannie Ferland & Available \\
\hline
\end{tabular}


Table 2. Continued.

\begin{tabular}{|c|c|c|c|c|}
\hline Year & Parameter & Sampling method & Principal investigators & Processed \\
\hline 2015 & Particulate mass & Sediment trap & Louis Fortier/Catherine Lalande & Available \\
\hline 2015 & Particulate nitrogen $(\mathrm{PN})$ & Camp water sample & Marcel Babin/Joannie Ferland & Available \\
\hline 2015 & Particulate nitrogen (PN) & Sediment trap & Louis Fortier/Catherine Lalande & $\begin{array}{l}\text { Data not } \\
\text { available yet }\end{array}$ \\
\hline 2015 & Particulate organic carbon (POC) & Sediment trap & Louis Fortier/ Catherine Lalande & Available \\
\hline 2015 & Particulate organic carbon (POC) & Camp water sample & Patrick Raimbault & Available \\
\hline 2015 & Particulate organic nitrogen (PON) & Camp water sample & Patrick Raimbault & Available \\
\hline 2015 & $\begin{array}{l}\text { Particulate organic phosphorus } \\
\text { (POP) }\end{array}$ & Camp water sample & Patrick Raimbault & $\begin{array}{l}\text { Data not } \\
\text { available yet }\end{array}$ \\
\hline 2015 & PDMPO uptake & Camp water sample & Aude Leynaert & $\begin{array}{l}\text { Data not } \\
\text { available yet }\end{array}$ \\
\hline 2015 & PDMPO uptake per species & Camp water sample & Aude Leynaert & $\begin{array}{l}\text { Data not } \\
\text { available yet }\end{array}$ \\
\hline 2015 & Phosphate $\left(\left(\mathrm{PO}_{4}\right)^{3-}\right)$ & Camp water sample & Patrick Raimbault & Available \\
\hline 2015 & Phosphate $\left(\left(\mathrm{PO}_{4}\right)^{3-}\right)$ & Sea-ice core & Patrick Raimbault & Available \\
\hline 2015 & $\begin{array}{l}\text { Photosynthetically available } \\
\text { radiation (PAR) }\end{array}$ & Surface mode & Marcel Babin/Martí Galí & Available \\
\hline 2015 & $\begin{array}{l}\text { Photosynthetically available } \\
\text { radiation (PAR) }\end{array}$ & Profile mode & Guislain Bécu/Marcel Babin & Available \\
\hline 2015 & $\begin{array}{l}\text { Photosynthetic nanoeukaryotes } \\
\text { (abundance) }\end{array}$ & Camp water sample & Daniel Vaulot/Dominique Marie & Available \\
\hline 2015 & Photosynthetic parameters & Camp water sample & Joannie Ferland/ Marcel Babin & Available \\
\hline 2015 & $\begin{array}{l}\text { Photosynthetic picoeukaryotes } \\
\text { (abundance) }\end{array}$ & Camp water sample & Daniel Vaulot/Dominique Marie & Available \\
\hline 2015 & Phytoplankton & Camp water sample & $\begin{array}{l}\text { Joannie Ferland/ } \\
\text { Pierre-Luc Grondin/ } \\
\text { Marcel Babin/Claudie Marec }\end{array}$ & Available \\
\hline 2015 & Phytoplankton (taxonomy) & Sediment trap & Louis Fortier/Catherine Lalande & Available \\
\hline 2015 & Pigments & Sea-ice core & Virginie Galindo/Søren Rysgaard & Available \\
\hline 2015 & Pigments & Camp water sample & Joséphine Ras/Hervé Claustre & Available \\
\hline 2015 & Primary production & Camp water sample & Patrick Raimbault & Available \\
\hline 2015 & $\operatorname{Rrs}\left(0^{+}\right)$ & Profile mode & Guislain Bécu/Marcel Babin & Available \\
\hline 2015 & Salinity & Sea-ice core & Virginie Galindo/Søren Rysgaard & Available \\
\hline 2015 & $\begin{array}{l}\text { Salinity-induced bacterial } \\
\text { biomarker }\end{array}$ & Ice core & $\begin{array}{l}\text { Rémi Amiraux/ } \\
\text { Jean-François Rontani }\end{array}$ & Available \\
\hline 2015 & $\begin{array}{l}\text { Salinity-induced bacterial } \\
\text { biomarker }\end{array}$ & Sediment trap & $\begin{array}{l}\text { Rémi Amiraux/ } \\
\text { Jean-François Rontani }\end{array}$ & Available \\
\hline 2015 & Sea-ice concentration & Surface mode & Philippe Massicotte & Available \\
\hline 2015 & Silica biogenic $(\mathrm{BSi})$ & Camp water sample & Aude Leynaert & Available \\
\hline 2015 & $\begin{array}{l}\text { Silica biogenic }(\mathrm{BSi}) \text { dissolution } \\
\text { rate }\end{array}$ & Camp water sample & Aude Leynaert & Available \\
\hline 2015 & $\begin{array}{l}\text { Silicate } \mathrm{Si}(\mathrm{OH})_{4} \text { absorption } \\
\text { kinetics }\end{array}$ & Camp water sample & Aude Leynaert & Available \\
\hline 2015 & Silica (uptake rate) & Camp water sample & Aude Leynaert & Available \\
\hline 2015 & Silicate $\mathrm{Si}(\mathrm{OH})_{4}$ & Camp water sample & Aude Leynaert & Available \\
\hline 2015 & Silicate $\mathrm{Si}(\mathrm{OH})_{4}$ & Camp water sample & Patrick Raimbault & Available \\
\hline 2015 & Silicate $\mathrm{Si}(\mathrm{OH})_{4}$ & Sea-ice core & Patrick Raimbault & Available \\
\hline 2015 & Snow depth & Camp snow sample & Virginie Galindo/Søren Rysgaard & Available \\
\hline 2015 & Snow depth & Meteorological tower & Guillaume Massé & Available \\
\hline
\end{tabular}


Table 2. Continued.

\begin{tabular}{|c|c|c|c|c|}
\hline Year & Parameter & Sampling method & Principal investigators & Processed \\
\hline 2015 & Sugars & Sediment trap & $\begin{array}{l}\text { Richard Sempéré/ } \\
\text { Christos Panagiotopoulos }\end{array}$ & Available \\
\hline 2015 & Surface albedo & Surface mode & Gauthier Verin/Ghislain Picard & Available \\
\hline 2015 & $\begin{array}{l}\text { Suspended particulate material } \\
\text { (SPM) }\end{array}$ & Camp water sample & Marcel Babin/Joannie Ferland & Available \\
\hline 2015 & Swimmers & Sediment trap & Louis Fortier/Catherine Lalande & Available \\
\hline 2015 & Synechococcus (abundance) & Camp water sample & Daniel Vaulot/Dominique Marie & Available \\
\hline 2015 & Temperature & Sea-ice core & Virginie Galindo/Søren Rysgaard & Available \\
\hline 2015 & Total organic carbon (TOC) & Rosette & $\begin{array}{l}\text { Richard Sempéré/ } \\
\text { Christos Panagiotopoulos }\end{array}$ & Available \\
\hline 2015 & Total organic carbon (TOC) & Camp water sample & Patrick Raimbault & Available \\
\hline 2015 & Total organic nitrogen $(\mathrm{TON})$ & Camp water sample & Patrick Raimbault & Available \\
\hline 2015 & Total organic phosphorus (TOP) & Camp water sample & Patrick Raimbault & Available \\
\hline 2015 & Transmittance through ice & Surface mode & Gauthier Verin & Available \\
\hline 2015 & $\begin{array}{l}\text { Under-ice export fluxes of biogenic } \\
\text { matter (fresh) }\end{array}$ & Sediment trap & Louis Fortier/Catherine Lalande & Available \\
\hline 2015 & Under-ice photos and video & $\begin{array}{l}\text { GoPro Hero } 4 \text { on radiometer } \\
\text { profiler }\end{array}$ & Eric Rehm & Available \\
\hline 2015 & Upwelling irradiance $\left(E_{\mathrm{u}}(z)\right)$ & Profile mode & Guislain Bécu/Marcel Babin & Available \\
\hline 2015 & Upwelling radiance $\left(L_{\mathrm{u}}(z)\right)$ & Surface mode & $\begin{array}{l}\text { Simon Bélanger/ } \\
\text { Clemence Goyens/ } \\
\text { Edouard Leymarie }\end{array}$ & Available \\
\hline 2015 & Upwelling radiance $\left(L_{\mathrm{u}}(z)\right)$ & Profile mode & Guislain Bécu/ Marcel Babin & Available \\
\hline 2015 & Vertical profile of snow density & Surface mode & Gauthier Verin/Ghislain Picard & Available \\
\hline 2015 & Vertical profile of specific surface area & Surface mode & Gauthier Verin/Florent Domine & Available \\
\hline 2015 & Virus (abundance) & Camp water sample & Fabien Joux & Available \\
\hline 2015 & Wind direction & Meteorological tower & Guillaume Massé & Available \\
\hline 2015 & Wind speed & Meteorological tower & Guillaume Massé & Available \\
\hline 2015 & Zooplankton (abundances) & Plankton net & Louis Fortier/Cyril Aubry & Available \\
\hline 2015 & Zooplankton (abundances) & Plankton net (LOKI) & Louis Fortier/Cyril Aubry & $\begin{array}{l}\text { Data not } \\
\text { available yet }\end{array}$ \\
\hline 2015 & Zooplankton (taxonomy) & Plankton net & Louis Fortier/Cyril Aubry & Available \\
\hline 2015 & Zooplankton (taxonomy) & Plankton net (LOKI) & Louis Fortier/Cyril Aubry & $\begin{array}{l}\text { Data not } \\
\text { available yet }\end{array}$ \\
\hline 2015 & Zooplankton vertical distribution & $\begin{array}{l}\text { Underwater vision profiler } \\
\text { (UVP) }\end{array}$ & $\begin{array}{l}\text { Claudie Marec/ } \\
\text { Sophie Renaut/Marc Picheral }\end{array}$ & Available \\
\hline 2016 & ${ }^{234} \mathrm{Th}$ (dissolved) & Rosette & Sabine Schmidt & $\begin{array}{l}\text { Data not } \\
\text { available yet }\end{array}$ \\
\hline 2016 & ${ }^{234} \mathrm{Th}$ (particulate) & Rosette & Sabine Schmidt & $\begin{array}{l}\text { Data not } \\
\text { available yet }\end{array}$ \\
\hline 2016 & Absorption coefficient & In-water IOP profiler & Guislain Bécu/Marcel Babin & Available \\
\hline 2016 & Absorption (particulate) & Camp ice sample & $\begin{array}{l}\text { Atsushi Matsuoka/ } \\
\text { Annick Bricaud/ } \\
\text { Joannie Ferland }\end{array}$ & Available \\
\hline 2016 & Absorption (particulate) & Camp water sample & $\begin{array}{l}\text { Atsushi Matsuoka/ } \\
\text { Annick Bricaud/Joannie Ferland }\end{array}$ & Available \\
\hline 2016 & ADCP (Mooring) & Mooring & $\begin{array}{l}\text { Laurent Oziel/ } \\
\text { Marie-Noëlle Houssais/ } \\
\text { Marcel Babin/José Lagunas }\end{array}$ & Available \\
\hline 2016 & Air relative humidity & Meteorological tower & Guillaume Massé & Available \\
\hline 2016 & Air temperature & Meteorological tower & Guillaume Massé & Available \\
\hline 2016 & Ammonium $\left(\mathrm{NH}_{4}^{+}\right)$ & Camp water sample & Patrick Raimbault & $\begin{array}{l}\text { Data not } \\
\text { available yet }\end{array}$ \\
\hline
\end{tabular}


Table 2. Continued.

\begin{tabular}{|c|c|c|c|c|}
\hline Year & Parameter & Sampling method & Principal investigators & Processed \\
\hline 2016 & Ammonium $\left(\mathrm{NH}_{4}^{+}\right.$, assimilation) & Camp water sample & Patrick Raimbault & Available \\
\hline 2016 & Ammonium $\left(\mathrm{NH}_{4}^{+}\right.$, regeneration) & Camp water sample & Patrick Raimbault & Available \\
\hline 2016 & Attenuation coefficient & In-water IOP profiler & Guislain Bécu/ Marcel Babin & Available \\
\hline 2016 & Backscattering coefficient & In-water IOP profiler & Guislain Bécu/ Marcel Babin & Available \\
\hline 2016 & Bacterial cultures & Camp water sample & Fabien Joux & Available \\
\hline 2016 & Bacterial cultures & Sea-ice core & Fabien Joux & Available \\
\hline 2016 & Bacterial production & Sea-ice core & Fabien Joux/Virginie Galindo & Available \\
\hline 2016 & Bacterial production & Camp water sample & Fabien Joux/Virginie Galindo & Available \\
\hline 2016 & Brine salinity and volume & Sea-ice core & Virginie Galindo/Søren Rysgaard & Available \\
\hline 2016 & Chlorophyll $a$ & In-water IOP profiler & Guislain Bécu/Marcel Babin & Available \\
\hline 2016 & Chlorophyll $a$ & Sediment trap & Louis Fortier/Catherine Lalande & Available \\
\hline 2016 & $\begin{array}{l}\text { Chlorophyll } a \text { and phaeopigments } \\
\text { (concentration) }\end{array}$ & Camp water sample & Marcel Babin/Joannie Ferland & Available \\
\hline 2016 & $\begin{array}{l}\text { Chromophoric dissolved organic } \\
\text { matter absorption }\end{array}$ & In-water IOP profiler & Guislain Bécu/Marcel Babin & Available \\
\hline 2016 & $\begin{array}{l}\text { Chromophoric dissolved organic } \\
\text { matter absorption }\end{array}$ & Camp water sample & $\begin{array}{l}\text { Atsushi Matsuoka/ } \\
\text { Joannie Ferland/Marcel Babin }\end{array}$ & Available \\
\hline 2016 & $\begin{array}{l}\text { Chromophoric dissolved organic } \\
\text { matter fluorescence }\end{array}$ & Camp water sample & $\begin{array}{l}\text { Atsushi Matsuoka/ } \\
\text { Joannie Ferland }\end{array}$ & Available \\
\hline 2016 & $\begin{array}{l}\text { Conductivity, temperature and } \\
\text { depth (CTD) }\end{array}$ & In-water IOP profiler & Guislain Bécu/Marcel Babin & Available \\
\hline 2016 & $\begin{array}{l}\text { Conductivity, temperature and } \\
\text { depth (CTD) }\end{array}$ & In-water profiler & Pascal Guillot/José Lagunas & Available \\
\hline 2016 & Cryptophytes (abundance) & Camp water sample & Daniel Vaulot & Available \\
\hline 2016 & Cultures of sorted populations & Camp water sample & Daniel Vaulot & Available \\
\hline 2016 & $\begin{array}{l}\text { Diatoms (Bacillariophyta) } \\
\text { abundance }\end{array}$ & Camp water sample & $\begin{array}{l}\text { Karine Leblanc/ } \\
\text { Bernard Quéguiner/ } \\
\text { Augustin Lafond }\end{array}$ & Available \\
\hline 2016 & $\begin{array}{l}\text { Diatoms (Bacillariophyta) } \\
\text { taxonomy }\end{array}$ & Camp water sample & $\begin{array}{l}\text { Karine Leblanc/ } \\
\text { Bernard Quéguiner/ } \\
\text { Augustin Lafond }\end{array}$ & Available \\
\hline 2016 & Diffuse attenuation coefficient $(\mathrm{Kd})$ & $\begin{array}{l}\text { Optical radiometer profiling } \\
\text { system }\end{array}$ & Guislain Bécu/Marcel Babin & Available \\
\hline 2016 & Dissolved organic carbon (HTCO) & Rosette & $\begin{array}{l}\text { Atsushi Matsuoka/ } \\
\text { Ronald Benner/Joannie Ferland }\end{array}$ & Available \\
\hline 2016 & $\begin{array}{l}\text { Dissolved organic matter } \\
\text { (Amino acids) }\end{array}$ & Rosette & $\begin{array}{l}\text { Atsushi Matsuoka/ } \\
\text { Ronald Benner/Joannie Ferland }\end{array}$ & Available \\
\hline 2016 & Dissolved organic matter (sugars) & Rosette & $\begin{array}{l}\text { Christos Panagiotopoulos/ } \\
\text { Richard Sempéré }\end{array}$ & Available \\
\hline 2016 & $\begin{array}{l}\text { Dissolved organic nitrogen } \\
\text { (release) }\end{array}$ & Camp water sample & Patrick Raimbault & Available \\
\hline 2016 & Downwelling irradiance & Surface mode & $\begin{array}{l}\text { Simon Bélanger/ } \\
\text { Clemence Goyens/ } \\
\text { Simon Lambert-Girard }\end{array}$ & Available \\
\hline 2016 & Downwelling irradiance & Surface mode & $\begin{array}{l}\text { Simon Lambert-Girard/ } \\
\text { Edouard Leymarie }\end{array}$ & $\begin{array}{l}\text { Data not } \\
\text { available yet }\end{array}$ \\
\hline 2016 & $\begin{array}{l}\text { Downwelling irradiance above the } \\
\text { surface }\left(E_{\mathrm{d}}\left(0^{+}\right)\right)\end{array}$ & Surface mode & Marcel Babin/Martí Galí & Available \\
\hline 2016 & $\begin{array}{l}\text { Downwelling irradiance above the } \\
\text { surface }\left(E_{\mathrm{d}}\left(0^{+}\right)\right)\end{array}$ & $\begin{array}{l}\text { Optical radiometer profiling } \\
\text { system }\end{array}$ & Guislain Bécu/Marcel Babin & Available \\
\hline
\end{tabular}


Table 2. Continued.

\begin{tabular}{|c|c|c|c|c|}
\hline Year & Parameter & Sampling method & Principal investigators & Processed \\
\hline 2016 & Downwelling irradiance $\left(E_{\mathrm{d}}(z)\right)$ & $\begin{array}{l}\text { Optical radiometer profiling } \\
\text { system }\end{array}$ & Guislain Bécu/Marcel Babin & Available \\
\hline 2016 & $\begin{array}{l}E_{\mathrm{d}}\left(0^{+}\right) \text {spectra from SBDART } \\
\text { radiative transfer simulations }\end{array}$ & Surface mode & Marcel Babin/Martí Galí & Available \\
\hline 2016 & Fecal pellets flux & Sediment trap & Louis Fortier/Catherine Lalande & $\begin{array}{l}\text { Data not } \\
\text { available yet }\end{array}$ \\
\hline 2016 & $\begin{array}{l}\text { Hemispherical directional } \\
\text { reflectance distribution function }\end{array}$ & Surface mode & $\begin{array}{l}\text { Simon Bélanger/ } \\
\text { Clemence Goyens/ } \\
\text { Simon Lambert-Girard }\end{array}$ & $\begin{array}{l}\text { Data not } \\
\text { available yet }\end{array}$ \\
\hline 2016 & Heterotrophic bacteria (abundance) & Camp water sample & Daniel Vaulot & Available \\
\hline 2016 & $\begin{array}{l}\text { Hydro SCAMP (temperature, salin- } \\
\text { ity, chlorophyll, turbidity, etc.) }\end{array}$ & In-water profiler & $\begin{array}{l}\text { Anda Vladoiu/ } \\
\text { Dany Dumont/Caroline Sévigny }\end{array}$ & Available \\
\hline 2016 & Ice and snow temperature & Meteorological tower & Guillaume Massé & $\begin{array}{l}\text { Data not } \\
\text { available yet }\end{array}$ \\
\hline 2016 & Ice thickness & Camp ice sample & Virginie Galindo/Søren Rysgaard & Available \\
\hline 2016 & Irradiance (downwelling) & Surface and ice-bottom mode & $\begin{array}{l}\text { Lisa Matthes/Jens Ehn/ } \\
\text { Simon Lambert-Girard/ } \\
\text { Christopher-John Mundy }\end{array}$ & Available \\
\hline 2016 & Irradiance (downwelling) & $\begin{array}{l}\text { Under-ice irradiance } \\
\text { transects, ROV }\end{array}$ & $\begin{array}{l}\text { Lisa Matthes/ } \\
\text { Simon Lambert-Girard/ } \\
\text { Jens Ehn/ } \\
\text { Christopher-John Mundy }\end{array}$ & Available \\
\hline 2016 & $\begin{array}{l}\text { Irradiance (downwelling, } \\
\text { upwelling) }\end{array}$ & $\begin{array}{l}\text { Surface water and underwater } \\
\text { profile mode }\end{array}$ & $\begin{array}{l}\text { Lisa Matthes/Jens Ehn/ } \\
\text { Simon Lambert-Girard/ } \\
\text { Christopher-John Mundy }\end{array}$ & Available \\
\hline 2016 & Isoprenoid lipids & Camp water sample & $\begin{array}{l}\text { Guillaume Massé/ } \\
\text { Caroline Guilmette }\end{array}$ & Available \\
\hline 2016 & Isoprenoid lipids & Sea-ice core & $\begin{array}{l}\text { Guillaume Massé/ } \\
\text { Caroline Guilmette }\end{array}$ & Available \\
\hline 2016 & Lipid biomarkers & Collected organisms & $\begin{array}{l}\text { Francis Dufour/ } \\
\text { Guillaume Massé/ } \\
\text { Pierre Ayotte/Mélanie Lemire }\end{array}$ & Available \\
\hline 2016 & Lipid tracers of bacteria stress & Camp water sample & $\begin{array}{l}\text { Jean-François Rontani/ } \\
\text { Rémi Amiraux }\end{array}$ & $\begin{array}{l}\text { Data not } \\
\text { available yet }\end{array}$ \\
\hline 2016 & Lipid tracers of bacteria stress & Sea-ice core & $\begin{array}{l}\text { Jean-François Rontani/ } \\
\text { Rémi Amiraux }\end{array}$ & $\begin{array}{l}\text { Data not } \\
\text { available yet }\end{array}$ \\
\hline 2016 & Lipid tracers of bacteria stress & Sediment trap & $\begin{array}{l}\text { Jean-François Rontani/ } \\
\text { Rémi Amiraux }\end{array}$ & $\begin{array}{l}\text { Data not } \\
\text { available yet }\end{array}$ \\
\hline 2016 & Nitrate $\left(\mathrm{NO}_{3}^{-}\right)$ & Camp water sample & Patrick Raimbault & Available \\
\hline 2016 & Nitrate $\left(\mathrm{NO}_{3}^{-}\right)$ & Sea-ice core & Patrick Raimbault & Available \\
\hline 2016 & Nitrate $\left(\mathrm{NO}_{3}^{-}\right.$, assimilation) & Camp water sample & Patrick Raimbault & Available \\
\hline 2016 & Nitrification & Camp water sample & Patrick Raimbault & Available \\
\hline 2016 & Nitrite $\left(\mathrm{NO}_{2}^{-}\right)$ & Camp water sample & Patrick Raimbault & Available \\
\hline 2016 & Nitrite $\left(\mathrm{NO}_{2}^{-}\right)$ & Sea-ice core & Patrick Raimbault & Available \\
\hline 2016 & Nutrients bioassay & Experiment & $\begin{array}{l}\text { Aurelie Delaforge/ } \\
\text { Christopher-John Mundy }\end{array}$ & $\begin{array}{l}\text { Data not } \\
\text { available yet }\end{array}$ \\
\hline 2016 & Nutrients bioassay & Experiment & Virginie Galindo/Søren Rysgaard & $\begin{array}{l}\text { Data not } \\
\text { available yet }\end{array}$ \\
\hline
\end{tabular}


Table 2. Continued.

\begin{tabular}{|c|c|c|c|c|}
\hline Year & Parameter & Sampling method & Principal investigators & Processed \\
\hline 2016 & $\begin{array}{l}\text { PAR from SBDART radiative } \\
\text { transfer simulations }\end{array}$ & Surface mode & Marcel Babin/Martí Galí & Available \\
\hline 2016 & Particle size distribution & In-water IOP profiler & Guislain Bécu/ Marcel Babin & $\begin{array}{l}\text { Data not } \\
\text { available yet }\end{array}$ \\
\hline 2016 & Particle size distribution & In-water profiler & Lars Stemmann/José Lagunas & Data not \\
\hline 2016 & Particles size & $\begin{array}{l}\text { Underwater vision profiler } \\
\text { (UVP) }\end{array}$ & José Lagunas/Marc Picheral & $\begin{array}{l}\text { available yet } \\
\text { Available }\end{array}$ \\
\hline 2016 & Particulate carbon (PC) & Camp water sample & Marcel Babin/Joannie Ferland & Available \\
\hline 2016 & Particulate mass & Sediment trap & Louis Fortier/Catherine Lalande & Available \\
\hline 2016 & Particulate nitrogen $(\mathrm{PN})$ & Camp water sample & Marcel Babin/Joannie Ferland & Available \\
\hline 2016 & Particulate nitrogen $(\mathrm{PN})$ & Sediment trap & Louis Fortier/Catherine Lalande & $\begin{array}{l}\text { Data not } \\
\text { available yet }\end{array}$ \\
\hline 2016 & Particulate organic carbon (POC) & Sediment trap & Louis Fortier/Catherine Lalande & Available \\
\hline 2016 & Particulate organic carbon (POC) & Camp water sample & Patrick Raimbault & Available \\
\hline 2016 & Particulate organic nitrogen (PON) & Camp water sample & Patrick Raimbault & Available \\
\hline 2016 & $\begin{array}{l}\text { Particulate organic phosphorus } \\
\text { (POP) }\end{array}$ & Camp water sample & Patrick Raimbault & $\begin{array}{l}\text { Data not } \\
\text { available yet }\end{array}$ \\
\hline 2016 & PDMPO uptake & Camp water sample & $\begin{array}{l}\text { Karine Leblanc/ } \\
\text { Bernard Quéguiner }\end{array}$ & $\begin{array}{l}\text { Data not } \\
\text { available yet }\end{array}$ \\
\hline 2016 & PDMPO uptake per species & Camp water sample & $\begin{array}{l}\text { Karine Leblanc/ } \\
\text { Bernard Quéguiner }\end{array}$ & $\begin{array}{l}\text { Data not } \\
\text { available yet }\end{array}$ \\
\hline 2016 & Phosphate $\left(\left(\mathrm{PO}_{4}\right)^{3-}\right)$ & Camp water sample & Patrick Raimbault & Available \\
\hline 2016 & Phosphate $\left(\left(\mathrm{PO}_{4}\right)^{3-}\right)$ & Sea-ice core & Patrick Raimbault & Available \\
\hline 2016 & $\begin{array}{l}\text { Photosynthetically available } \\
\text { radiation (PAR) }\end{array}$ & Surface mode & Marcel Babin/Martí Galí & Available \\
\hline 2016 & $\begin{array}{l}\text { Photosynthetically available } \\
\text { radiation (PAR) }\end{array}$ & $\begin{array}{l}\text { Optical radiometer profiling } \\
\text { system }\end{array}$ & Guislain Bécu/Marcel Babin & Available \\
\hline 2016 & $\begin{array}{l}\text { Photosynthetic eukaryotes } \\
\text { (morphology) }\end{array}$ & Camp water sample & Daniel Vaulot & $\begin{array}{l}\text { Data not } \\
\text { available yet }\end{array}$ \\
\hline 2016 & $\begin{array}{l}\text { Photosynthetic nanoeukaryotes } \\
\text { (abundance) }\end{array}$ & Camp water sample & Daniel Vaulot & Available \\
\hline 2016 & Photosynthetic parameters & Camp water sample & Joannie Ferland/Marcel Babin & Available \\
\hline 2016 & $\begin{array}{l}\text { Photosynthetic parameters } \\
\text { (variable fluorescence) }\end{array}$ & Camp water sample & $\begin{array}{l}\text { Johann Lavaud/ } \\
\text { Virginie Galindo/Søren Rysgaard }\end{array}$ & Available \\
\hline 2016 & $\begin{array}{l}\text { Photosynthetic parameters } \\
\text { (variable fluorescence) }\end{array}$ & Sediment trap & $\begin{array}{l}\text { Johann Lavaud/ } \\
\text { Virginie Galindo/Søren Rysgaard }\end{array}$ & Available \\
\hline 2016 & $\begin{array}{l}\text { Photosynthetic parameters } \\
\text { (variable fluorescence) }\end{array}$ & Sea-ice core & $\begin{array}{l}\text { Johann Lavaud/ } \\
\text { Virginie Galindo/Søren Rysgaard }\end{array}$ & Available \\
\hline 2016 & $\begin{array}{l}\text { Photosynthetic picoeukaryotes } \\
\text { (abundance) }\end{array}$ & Camp water sample & Daniel Vaulot & Available \\
\hline 2016 & Phytoplankton & Camp water sample & $\begin{array}{l}\text { Joannie Ferland/ } \\
\text { Pierre-Luc Grondin/ } \\
\text { Marcel Babin }\end{array}$ & Available \\
\hline 2016 & Phytoplankton (taxonomy) & Sediment trap & Louis Fortier/Catherine Lalande & Available \\
\hline 2016 & Pigments & Camp water sample & $\begin{array}{l}\text { Joséphine Ras/ } \\
\text { Hervé Claustre/ } \\
\text { Virginie Galindo/Søren Rysgaard }\end{array}$ & Available \\
\hline 2016 & Primary production & Camp water sample & Patrick Raimbault & Available \\
\hline 2016 & Prokaryotic diversity & Camp water sample & Fabien Joux & $\begin{array}{l}\text { Data not } \\
\text { available yet }\end{array}$ \\
\hline
\end{tabular}


Table 2. Continued.

\begin{tabular}{|c|c|c|c|c|}
\hline Year & Parameter & Sampling method & Principal investigators & Processed \\
\hline 2016 & Prokaryotic diversity & Sea-ice core & Fabien Joux & $\begin{array}{l}\text { Data not } \\
\text { available yet }\end{array}$ \\
\hline 2016 & $\operatorname{Rrs}\left(0^{+}\right)$ & $\begin{array}{l}\text { Optical radiometer profiling } \\
\text { system }\end{array}$ & Guislain Bécu/Marcel Babin & Available \\
\hline 2016 & Salinity & Sea-ice core & Virginie Galindo/Søren Rysgaard & Available \\
\hline 2016 & Scattering coefficient & In-water IOP profiler & Guislain Bécu/Marcel Babin & Available \\
\hline 2016 & Sea-ice concentration & Surface mode & Philippe Massicotte & Available \\
\hline 2016 & Selenium & Collected organisms & $\begin{array}{l}\text { Francis Dufour/ } \\
\text { Guillaume Massé/ } \\
\text { Pierre Ayotte/Mélanie Lemire }\end{array}$ & Available \\
\hline 2016 & Silica biogenic (BSi) & Camp water sample & $\begin{array}{l}\text { Aude Leynaert/ } \\
\text { Brivaela Moriceau/ } \\
\text { Karine Leblanc/ } \\
\text { Bernard Quéguiner }\end{array}$ & Available \\
\hline 2016 & $\begin{array}{l}\text { Silica biogenic }(\mathrm{BSi}) \text { dissolution } \\
\text { rate }\end{array}$ & Camp water sample & Brivaela Moriceau & Available \\
\hline 2016 & Silica lithogenic (LSi) & Camp water sample & $\begin{array}{l}\text { Aude Leynaert/ } \\
\text { Brivaela Moriceau/ } \\
\text { Karine Leblanc/ } \\
\text { Bernard Quéguiner }\end{array}$ & $\begin{array}{l}\text { Data not } \\
\text { available yet }\end{array}$ \\
\hline 2016 & $\begin{array}{l}\text { Silicate } \mathrm{Si}(\mathrm{OH})_{4} \text { absorption } \\
\text { kinetics }\end{array}$ & Camp water sample & Aude Leynaert & Available \\
\hline 2016 & Silica (uptake rate) & Camp water sample & Aude Leynaert & Available \\
\hline 2016 & Silicate $\mathrm{Si}(\mathrm{OH})_{4}$ & Camp water sample & $\begin{array}{l}\text { Aude Leynaert/ } \\
\text { Brivaela Moriceau }\end{array}$ & Available \\
\hline 2016 & Silicate $\mathrm{Si}(\mathrm{OH})_{4}$ & Camp water sample & Patrick Raimbault & Available \\
\hline 2016 & Silicate $\mathrm{Si}(\mathrm{OH})_{4}$ & Sea-ice core & Patrick Raimbault & Available \\
\hline 2016 & Snow depth & Camp snow sample & Virginie Galindo/Søren Rysgaard & Available \\
\hline 2016 & $\begin{array}{l}\text { Spectral downwelling radiance } \\
\text { angular distribution }\end{array}$ & Underwater sensor & $\begin{array}{l}\text { Simon Lambert-Girard/ } \\
\text { Edouard Leymarie }\end{array}$ & Available \\
\hline 2016 & Spectral transmittance through ice & Surface mode & Gauthier Verin/Ghislain Picard & Available \\
\hline 2016 & Surface spectral albedo & Surface mode & Gauthier Verin/Ghislain Picard & Available \\
\hline 2016 & $\begin{array}{l}\text { Suspended particulate material } \\
\text { (SPM) }\end{array}$ & Camp water sample & Marcel Babin/Joannie Ferland & Available \\
\hline 2016 & Swimmers & Sediment trap & Louis Fortier/Catherine Lalande & Available \\
\hline 2016 & Synechococcus (abundance) & Camp water sample & Daniel Vaulot & Available \\
\hline 2016 & Temperature & Sea-ice core & Virginie Galindo/Søren Rysgaard & Available \\
\hline 2016 & Total organic carbon (TOC) & Camp water sample & Patrick Raimbault & Available \\
\hline 2016 & $\begin{array}{l}\text { Total organic carbon (TOC) and } \\
\text { dissolved organic carbon (DOC) }\end{array}$ & Rosette & $\begin{array}{l}\text { Christos Panagiotopoulos/ } \\
\text { Richard Sempéré }\end{array}$ & Available \\
\hline 2016 & Total organic nitrogen $(\mathrm{TON})$ & Camp water sample & Patrick Raimbault & Available \\
\hline 2016 & Total organic phosphorus (TOP) & Camp water sample & Patrick Raimbault & Available \\
\hline 2016 & $\begin{array}{l}\text { Under-ice export fluxes of biogenic } \\
\text { matter (fresh) }\end{array}$ & Sediment trap & Louis Fortier/Catherine Lalande & Available \\
\hline 2016 & Upwelling irradiance $\left(E_{\mathrm{u}}(z)\right)$ & $\begin{array}{l}\text { Optical radiometer profiling } \\
\text { system }\end{array}$ & Guislain Bécu/Marcel Babin & Available \\
\hline 2016 & Upwelling radiance $\left(L_{\mathrm{u}}(z)\right)$ & Surface mode & $\begin{array}{l}\text { Simon Bélanger/ } \\
\text { Clemence Goyens/ } \\
\text { Simon Lambert-Girard }\end{array}$ & $\begin{array}{l}\text { Data not } \\
\text { available yet }\end{array}$ \\
\hline 2016 & Upwelling radiance $\left(L_{\mathrm{u}}(z)\right)$ & $\begin{array}{l}\text { Optical radiometer profiling } \\
\text { system }\end{array}$ & Guislain Bécu/Marcel Babin & Available \\
\hline
\end{tabular}


Table 2. Continued.

\begin{tabular}{|c|c|c|c|c|}
\hline Year & Parameter & Sampling method & Principal investigators & Processed \\
\hline 2016 & Vertical profile of snow density & Surface mode & Gauthier Verin/Ghislain Picard & Available \\
\hline 2016 & $\begin{array}{l}\text { Vertical profile of specific surface } \\
\text { area }\end{array}$ & Surface mode & Gauthier Verin/Florent Domine & Available \\
\hline 2016 & Virus (abundance) & Camp water sample & Fabien Joux & Available \\
\hline 2016 & Wind direction & Meteorological tower & Guillaume Massé & Available \\
\hline 2016 & Wind speed & Meteorological tower & Guillaume Massé & Available \\
\hline 2016 & Zooplankton (abundances) & Plankton net & Louis Fortier/Cyril Aubry & Available \\
\hline 2016 & $\begin{array}{l}\text { Zooplankton fecal pellet production } \\
\text { rate }\end{array}$ & Plankton net & Louis Fortier/Makoto Sampei & $\begin{array}{l}\text { Data not } \\
\text { available yet }\end{array}$ \\
\hline 2016 & Zooplankton grazing rate & Plankton net & Louis Fortier/Makoto Sampei & $\begin{array}{l}\text { Data not } \\
\text { available yet }\end{array}$ \\
\hline 2016 & Zooplankton (taxonomy) & Plankton net & Louis Fortier/Cyril Aubry & Available \\
\hline 2016 & Zooplankton vertical distribution & $\begin{array}{l}\text { Underwater vision profiler } \\
\text { (UVP) }\end{array}$ & José Lagunas/Marc Picheral & Available \\
\hline
\end{tabular}

the Arctic PSB. In this paper, only a handful of variables have been presented. The reader can find the complete list of measured variables in Table 2, all of which are also fully available in the data repository. Furthermore, a collection of scientific research papers is currently being submitted to a special issue of the Elementa journal entitled "Green Edge The phytoplankton spring bloom in the Arctic Ocean: past, present and future response to climate variations, and impact on carbon fluxes and the marine food web". The uniqueness and comprehensiveness of this dataset offer more opportunities to reuse it for other applications. 


\section{Appendix A: Surface tidal height}

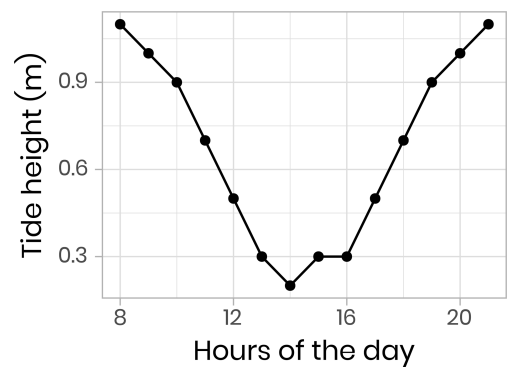

Figure A1. Surface tidal height vs. time at Qikiqtarjuaq measured on 9 June 2015. 


\section{Appendix B: GoPro Hero 4 photos}

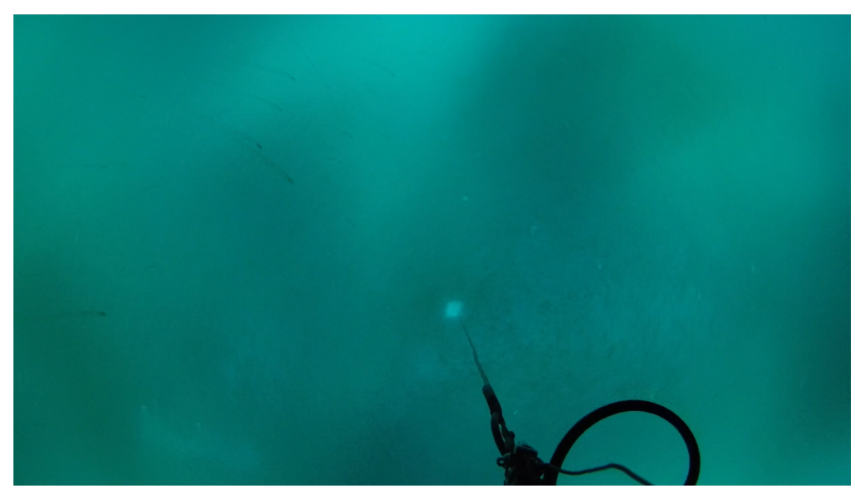

Figure B1. Video frame (00:58) from GoPro Hero 4 recording of COPS descent from 0 to $30 \mathrm{~m}, 18$ May 2015 at the "low snow" hole. Note the streaks of nekton swimming across the upper left quadrant of the frame. Many plankton were seen in this profile, indicating an active under-ice community. A profile of the "high snow" hole on the same day, just $40 \mathrm{~m}$ away, showed no such plankton activity.

Table B1. Examples of GoPro Hero 4 photos at the low and high snow holes in 2015 demonstrating the spatial variability of the ice bottom across time and space.

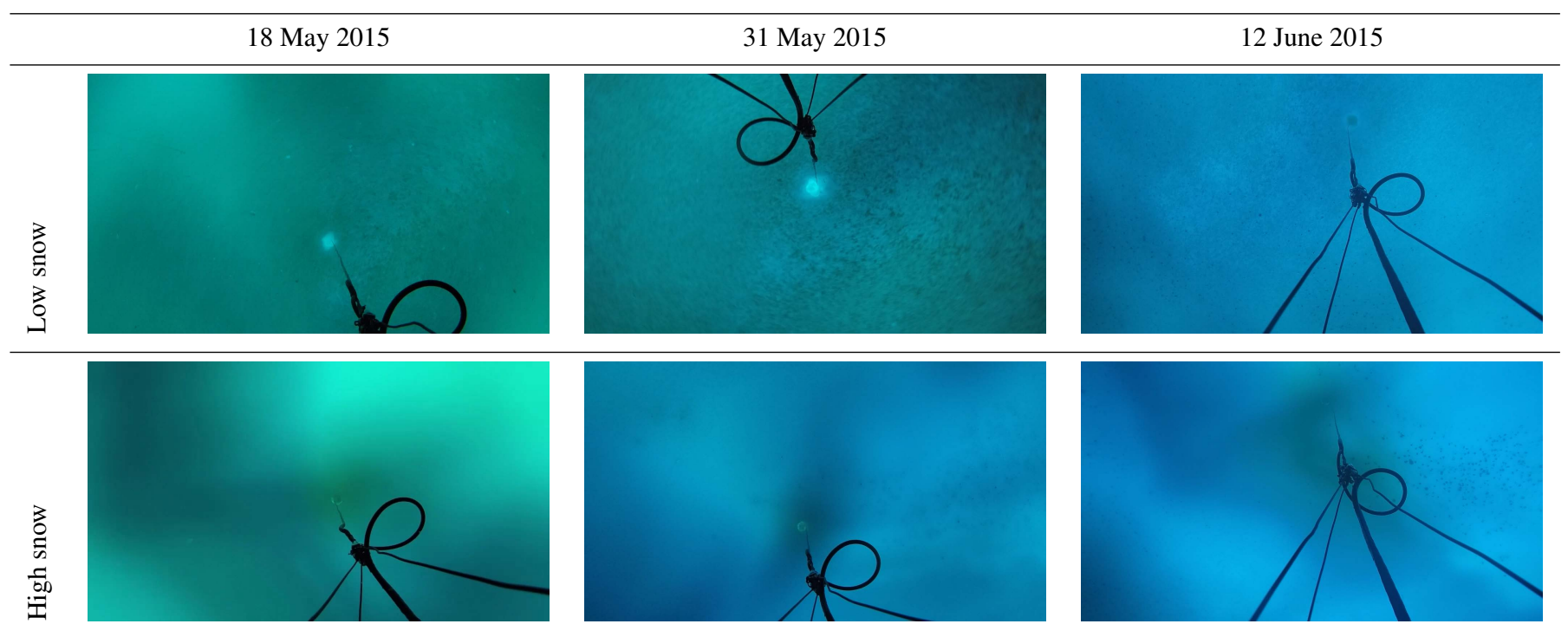


Author contributions. GP and LaA designed the snow optical measurements. GP participated in the 2015 campaign, along with GV, who performed the 2015 and 2016 snow-related measurements. AV, CarS and DD deployed the Self-Contained Autonomous MicroProfiler (SCAMP) on 23 June 2016 and quality-controlled, processed, analyzed and interpreted the data, with $\mathrm{MNH}$ adding her contribution to the analysis. GB, CIM performed the setup and deployment of the CTD inside the tent in 2015. CTD setup and deployment was performed by JosL and ChD in 2016. GB, GN, EricR, SLG, LO, JaL, JF and JuL performed the setup, calibration and deployments of the ICE-Pro optical profiler outside the tent and the IOP frame inside the tent. EricR performed the $13 \mathrm{~h}$ tidal cycle measurements in 2015. GN and EricR deployed the GoPro Hero on the ICE-Pro. ClM performed the setup and installation of IFCB in the lab in 2015. JF performed the setup and installation of the IFCB in the lab in 2016. JF, ErinR, AM, MHF and PLG performed the measurements. PLG analyzed the data. CIM and JosL performed the setup and deployment of an in-water profiler for particle size distribution and zooplankton vertical distribution (UVP, underwater vision profiler). ClM and JosL performed the setup and water sampling in both 2015 and 2016 campaigns. ClM was involved in the design and deployment of the ADCP in 2015, and JosL deployed the instrument in 2016. AM coordinated the sampling strategy of discrete waters in terms of examining the linkages between optical and organic matter properties. $\mathrm{AM}$ and $\mathrm{AB}$ wrote the protocols for both CDOM and particulate absorption. For CDOM, AM, JF, MHF, ErinR and PLG contributed to the measurements. For AP, AM, CéD, LL, JR, MA, HCB, BSB and TL contributed to the measurements. In 2015, particulate spectral absorption was also measured by LM, CQ and JE. NP also did snow and ice salinity and overall chl $a$ filtrations in the field lab. MPA worked on tidying and uniformizing the data. MartG ran the radiative transfer calculations and compared them to irradiance measurements taken on the ice camps. LM, SLG, RH, JE, NP and CJM designed and/or carried out the TriOS and remotely operated vehicle under-ice irradiance measurements. CP and RS coordinated the sampling strategy for sugars and DOC and the analyses. RA collected the samples. Between October 2014 and July 2016, ÉB and FPdS conducted measurements, collected clams, maintained equipment, kept a time-lapse photography record and represented the Green Edge team in Qikiqtarjuaq outside of the sampling season. DCS coordinated logistics in Qikiqtarjuaq, in support of the 2016 ice camp. MS designed and carried out copepods incubations to collect fecal pellets out at the ice camp in 2016. MS made microscopic observations of the collected fecal pellets in the laboratory. Sea ice and snow hemispherical directional reflectance were measured on the ice camp in 2015 by SM and ClG. The setup was designed by SM, EL, SB and ClG. They also processed and analyzed the data. CatS, the LEFE-CYBER database manager is acknowledged for her help in gathering the data presented. FID designed the snow-specific surface area measurements and participated in the 2015 campaign, along with GV, who performed the 2015 and 2016 snow-related measurements. DV, ALdS, IP and PrG sampled at the ice camp for flow cytometry, phytoplankton cultures and molecular biology. CGR, ALdS, PrG and FLG established phytoplankton culture isolates. DoM and MT performed flow cytometry measurements for the 2015 and 2016 ice camp samples. DaM analyzed and plotted the flow cytometry data. FJ and VG measured the bacterial production during the 2016 ice camp.
NM was at the LOCEAN when he participated to GreenEdge. He contributed to field operations by installing the Ice-T mooring and measuring sea ice and under ice physical properties.

Competing interests. The authors declare that they have no conflict of interest.

Acknowledgements. This project would not have been possible without the support of the hamlet of Qikiqtarjuaq and the members of the community, as well as the Inuksuit School and its Principal Jacqueline Arsenault. The project was conducted under the scientific coordination of the Canada Excellence Research Chair in Remote Sensing of Canada's new Arctic frontier and the CNRS and Université Laval Takuvik Joint International laboratory (UMI3376). The field campaign was successful thanks to the contribution of Andrew Wells, Maxime Benoit-Gagné and Emmanuel Devred from the Takuvik laboratory, as well as Robert Hodgson from the University of Manitoba. Thanks are given to Pascale Bouruet-Aubertot and Yannis Cuypers, who provided the SCAMP and contributed to the processing, quality control, analysis and interpretation of the data. We also thank Michel Gosselin, Québec-Océan, the CCGS Amundsen and the Polar Continental Shelf Program for their in-kind contribution to the logistic and scientific equipment. Thanks to Etienne Ouellet for IT support and data infrastructure management. Scientific research licenses for both 2015 (NRI license 01010 15-N-M) and 2016 (NRI license 01001 15-R-M) were kindly accorded by the Nunavut Research Institute.

Financial support. The Green Edge project is funded by the following French and Canadian programs and agencies: ANR (contract no. 111112), CNES (project no. 131425), IPEV (project no. 1164), CSA, Fondation Total, ArcticNet, LEFE and the French Arctic Initiative (Green Edge project).

Review statement. This paper was edited by Giuseppe M. R. Manzella and reviewed by two anonymous referees.

\section{References}

Aminot, A. and Kérouel, R.: Dosage automatique des nutriments dans les eaux marines : méthodes en flux continu, Ifremer, 2007.

Ardyna, M., Babin, M., Gosselin, M., Devred, E., Bélanger, S., Matsuoka, A., and Tremblay, J.-É.: Parameterization of vertical chlorophyll a in the Arctic Ocean: impact of the subsurface chlorophyll maximum on regional, seasonal, and annual primary production estimates, Biogeosciences, 10, 4383-4404, https://doi.org/10.5194/bg-10-4383-2013, 2013.

Arrigo, K. R., Perovich, D. K., Pickart, R. S., Brown, Z. W., van Dijken, G. L., Lowry, K. E., Mills, M. M., Palmer, M. A., Balch, W. M., Bahr, F., Bates, N. R., Benitez-Nelson, C., Bowler, B., Brownlee, E., Ehn, J. K., Frey, K. E., Garley, R., Laney, S. R., Lubelczyk, L., Mathis, J., Matsuoka, A., Mitchell, B. G., Moore, G. W. K., Ortega-Retuerta, E., Pal, S., Polashenski, C. M., Reynolds, R. A., Schieber, B., Sosik, 
H. M., Stephens, M., and Swift, J. H.: Massive Phytoplankton Blooms Under Arctic Sea Ice, Science, 336, 1408-1408, https://doi.org/10.1126/science.1215065, 2012.

Arrigo, K. R., Perovich, D. K., Pickart, R. S., Brown, Z. W., van Dijken, G. L., Lowry, K. E., Mills, M. M., Palmer, M. A., Balch, W. M., Bates, N. R., Benitez-Nelson, C. R., Brownlee, E., Frey, K. E., Laney, S. R., Mathis, J., Matsuoka, A., Greg Mitchell, B., Moore, G., Reynolds, R. A., Sosik, H. M., and Swift, J. H.: Phytoplankton blooms beneath the sea ice in the Chukchi sea, Deep-Sea Res. Pt. II, 105, 1-16, https://doi.org/10.1016/j.dsr2.2014.03.018, 2014.

Assmy, P., Fernández-Méndez, M., Duarte, P., Meyer, A., Randelhoff, A., Mundy, C. J., Olsen, L. M., Kauko, H. M., Bailey, A., Chierici, M., Cohen, L., Doulgeris, A. P., Ehn, J. K., Fransson, A., Gerland, S., Hop, H., Hudson, S. R., Hughes, N., Itkin, P., Johnsen, G., King, J. A., Koch, B. P., Koenig, Z., Kwasniewski, S., Laney, S. R., Nicolaus, M., Pavlov, A. K., Polashenski, C. M., Provost, C., Rösel, A., Sandbu, M., Spreen, G., Smedsrud, L. H., Sundfjord, A., Taskjelle, T., Tatarek, A., Wiktor, J., Wagner, P. M., Wold, A., Steen, H., and Granskog, M. A.: Leads in Arctic pack ice enable early phytoplankton blooms below snow-covered sea ice, Sci. Rep., 7, 40850, https://doi.org/10.1038/srep40850, 2017.

Bouman, H. A., Platt, T., Doblin, M., Figueiras, F. G., Gudmundsson, K., Gudfinnsson, H. G., Huang, B., Hickman, A., Hiscock, M., Jackson, T., Lutz, V. A., Mélin, F., Rey, F., Pepin, P., Segura, V., Tilstone, G. H., van Dongen-Vogels, V., and Sathyendranath, S.: Photosynthesis-irradiance parameters of marine phytoplankton: synthesis of a global data set, Earth Syst. Sci. Data, 10, 251266, https://doi.org/10.5194/essd-10-251-2018, 2018.

Fortier, M., Fortier, L., Michel, C., and Legendre, L.: Climatic and biological forcing of the vertical flux of biogenic particles under seasonal Arctic sea ice, Mar. Ecol. Prog. Ser., 225, 1-16, https://doi.org/10.3354/meps225001, 2002.

Galindo, V., Levasseur, M., Mundy, C. J., Gosselin, M., Tremblay, J.-É., Scarratt, M., Gratton, Y., Papakiriakou, T., Poulin, M., and Lizotte, M.: Biological and physical processes influencing sea ice, under-ice algae, and dimethylsulfoniopropionate during spring in the Canadian Arctic Archipelago, J. Geophys. Res. Ocean., 119, 3746-3766, https://doi.org/10.1002/2013JC009497, 2014.

Galindo, V., Gosselin, M., Lavaud, J., Mundy, C., Else, B., Ehn, J., Babin, M., and Rysgaard, S.: Pigment composition and photoprotection of Arctic sea ice algae during spring, Mar. Ecol. Prog. Ser., 585, 49-69, https://doi.org/10.3354/meps12398, 2017.

Gosselin, M., Levasseur, M., Wheeler, P. A., Horner, R. A., and Booth, B. C.: New measurements of phytoplankton and ice algal production in the Arctic Ocean, Deep-Sea Res. Pt. II, 44, 1623 1644, https://doi.org/10.1016/S0967-0645(97)00054-4, 1997.

Goyens, C., Marty, S., Leymarie, E., Antoine, D., Babin, M., and Bélanger, S.: High Angular Resolution Measurements of the Anisotropy of Reflectance of Sea Ice and Snow, Earth Sp. Sci., 5, 30-47, https://doi.org/10.1002/2017EA000332, 2018.

Grondin, P.-L., Ferland, J., Massicotte, P., Galindo, V., Ras, J., Claustre, H., Garcia, N., Raimbault, P., Coupel, P., Tremblay, J.É., Forget, M.-H., Karp-Boss, L., and Babin, M.: Protists succession from ice algae to under-ice phytoplankton spring blooms in Baffin Bay, in preparation, 2019.
Laliberté, J., Bélanger, S., and Frouin, R.: Evaluation of satellite-based algorithms to estimate photosynthetically available radiation (PAR) reaching the ocean surface at high northern latitudes, Remote Sens. Environ., 184, 199-211, https://doi.org/10.1016/j.rse.2016.06.014, 2016.

Laney, S. R. and Sosik, H. M.: Phytoplankton assemblage structure in and around a massive under-ice bloom in the Chukchi Sea, Deep-Sea Res. Pt. II, 105, 30-41, https://doi.org/10.1016/j.dsr2.2014.03.012, 2014.

LEFE-CYBER: GREEN EDGE, available at: http://www.obs-vlfr. fr/proof/php/GREENEDGE/greenedge.php, last access: 2 December 2019.

Letelier, R. M., Karl, D. M., Abbott, M. R., and Bidigare, R. R.: Light driven seasonal patterns of chlorophyll and nitrate in the lower euphotic zone of the North Pacific Subtropical Gyre, Limnol. Oceanogr., 49, 508-519, https://doi.org/10.4319/lo.2004.49.2.0508, 2004.

Leu, E., Mundy, C., Assmy, P., Campbell, K., Gabrielsen, T., Gosselin, M., Juul-Pedersen, T., and Gradinger, R.: Arctic spring awakening - Steering principles behind the phenology of vernal ice algal blooms, Prog. Oceanogr., 139, 151-170, https://doi.org/10.1016/j.pocean.2015.07.012, 2015.

Marie, D., Partensky, F., Jacquet, S., and Vaulot, D.: Enumeration and Cell Cycle Analysis of Natural Populations of Marine Picoplankton by Flow Cytometry Using the Nucleic Acid Stain SYBR Green I., Appl. Environ. Microbiol., 63, 186-193, 1997.

Marie, D., Rigaut-Jalabert, F., and Vaulot, D.: An improved protocol for flow cytometry analysis of phytoplankton cultures and natural samples, Cytom. Part A, 85, 962-968, https://doi.org/10.1002/cyto.a.22517, 2014.

Massicotte, P., Bécu, G., Lambert-Girard, S., Leymarie, E., and Babin, M.: Estimating Underwater Light Regime under Spatially Heterogeneous Sea Ice in the Arctic, Appl. Sci., 8, 2693, https://doi.org/10.3390/app8122693, 2018.

Massicotte, P., Amiraux, R., Amyot, M.-P., Archambault, P., Ardyna, M., Arnaud, L., Artigue, L., Aubry, C., Ayotte, P., Bécu, G., Bélanger, S., Benner, R., Bittig, H. C., Bricaud, A., Brossier, É., Bruyant, F., Chauvaud, L., Christiansen-Stowe, D., Claustre, H., Cornet-Barthaux, V., Coupel, P., Cox, C., Delaforge, A., Dezutter, T., Dimier, C., Domine, F., Dufour, F., Dufresne, C., Dumont, D., Ehn, J., Else, B., Ferland, J., Forget, M.-H., Fortier, L., Galí, M., Galindo, V., Gallinari, M., Garcia, N., GérikasRibeiro, C., Gourdal, M., Gourvil, P., Goyens, C., Grondin, P.L., Guillot, P., Guilmette, C., Houssais, M.-N., Joux, F., Lacour, L., Lacour, T., Lafond, A., Lagunas, J., Lalande, C., Laliberté, J., Lambert-Girard, S., Larivière, J., Lavaud, J., Lebaron, A., Leblanc, K., Le Gall, F., Legras, J., Lemire, M., Levasseur, M., Leymarie, E., Leynaert, A., Lopes Dos Santos, A., Lourenço, A., Mah, D., Marec, C., Marie, D., Martin, N., Marty, C., Marty, S., Massé, G., Matsuoka, A., Matthes, L., Moriceau, B., Muller, P.E., Mundy, C. J., Neukermans, G., Oziel, L., Panagiotopoulos, C., Pangazi, J.-J., Picard, G., Picheral, M., Pinczon Du Sel, F., Pogorzelec, N., Probert, I., Queguiner, B., Raimbault, P., Ras, J., Rehm, E., Reimer, E., Rontani, J.-F., Rysgaard, S., SaintBéat, B., Sampei, M., Sansoulet, J., Schmidt, S., Sempéré, R., Sévigny, C., Shen, Y., Tragin, M., Tremblay, J.-É., Vaulot, D., Verin, G., Vivier, F., Vladoiu, A., Whitehead, J., and Babin, M.: The Green Edge initiative: understanding the processes control- 
ling the under-ice Arctic phytoplankton spring bloom, SEANOE, https://doi.org/10.17882/59892, 2019a.

Massicotte, P., Peeken, I., Katlein, C., Flores, H., Huot, Y., Castellani, G., Arndt, S., Lange, B. A., Tremblay, J.-É., and Babin, M.: Sensitivity of Phytoplankton Primary Production Estimates to Available Irradiance Under Heterogeneous Sea Ice Conditions, J. Geophys. Res. Ocean., 124, 5436-5450, https://doi.org/10.1029/2019JC015007, 2019b.

Matthes, L. C., Ehn, J. K., L.-Girard, S., Pogorzelec, N. M., Babin, M., and Mundy, C. J.: Average cosine coefficient and spectral distribution of the light field under sea ice: Implications for primary production, Elem. Sci. Anth., 7, 25, https://doi.org/10.1525/elementa.363, 2019.

Menden-Deuer, S. and Lessard, E. J.: Carbon to volume relationships for dinoflagellates, diatoms, and other protist plankton, Limnol. Oceanogr., 45, 569-579, https://doi.org/10.4319/lo.2000.45.3.0569, 2000.

Moberg, E. A. and Sosik, H. M.: Distance maps to estimate cell volume from two-dimensional plankton images, Limnol. Oceanogr.Meth., 10, 278-288, https://doi.org/10.4319/lom.2012.10.278, 2012.

Mundy, C., Gosselin, M., Gratton, Y., Brown, K., Galindo, V., Campbell, K., Levasseur, M., Barber, D., Papakyriakou, T., and Bélanger, S.: Role of environmental factors on phytoplankton bloom initiation under landfast sea ice in Resolute Passage, Canada, Mar. Ecol. Prog. Ser., 497, 39-49, https://doi.org/10.3354/meps10587, 2014.

Mundy, C. J., Gosselin, M., Ehn, J., Gratton, Y., Rossnagel, A., Barber, D. G., Martin, J., Tremblay, J.-É., Palmer, M., Arrigo, K. R., Darnis, G., Fortier, L., Else, B., and Papakyriakou, T.: Contribution of under-ice primary production to an ice-edge upwelling phytoplankton bloom in the Canadian Beaufort Sea, Geophys. Res. Lett., 36, L17601, https://doi.org/10.1029/2009GL038837, 2009.

Olson, R. J. and Sosik, H. M.: A submersible imaging-inflow instrument to analyze nano-and microplankton: Imaging FlowCytobot, Limnol. Oceanogr.- Meth., 5, 195-203, https://doi.org/10.4319/lom.2007.5.195, 2007.

Oziel, L., Massicotte, P., Randelhoff, A., Ferland, J., Vladoiu, A., Lacour, L., Galindo, V., Lambert-Girard, S., Dumont, D., Cuypers, Y., Bouruet-Aubertot, P., Mundy, C.-J., Ehn, J., Bécu, G., Marec, C., Forget, M.-H., Garcia, N., Coupel, P., Raimbault, P., Houssais, M.-N., and Babin, M.: Environmental factors influencing the seasonal dynamics of spring algal blooms in and beneath sea ice in western Baffin Bay, Elem. Sci. Anth., 7, 34, https://doi.org/10.1525/elementa.372, 2019.

Perrette, M., Yool, A., Quartly, G. D., and Popova, E. E.: Nearubiquity of ice-edge blooms in the Arctic, Biogeosciences, 8, 515-524, https://doi.org/10.5194/bg-8-515-2011, 2011.

Picheral, M., Colin, S., and Irisson, J.-O.: EcoTaxa, a tool for the taxonomic classification of images, available at: http://ecotaxa. obs-vlfr.fr (last access: 2 December 2019), 2017.

Raimbault, P., Slawyk, G., Boudjellal, B., Coatanoan, C., Conan, P., Coste, B., Garcia, N., Moutin, T., and Pujo-Pay, M.: Carbon and nitrogen uptake and export in the equatorial Pacific at $150^{\circ} \mathrm{W}$ : Evidence of an efficient regenerated production cycle, J. Geophys. Res.-Oceans, 104, 3341-3356, https://doi.org/10.1029/1998JC900004, 1999.
Randelhoff, A., Oziel, L., Massicotte, P., Bécu, G., Galí, M., Lacour, L., Dumont, D., Vladoiu, A., Marec, C., Bruyant, F., Houssais, M.-N., Tremblay, J.-É., Deslongchamps, G., and Babin, M.: The evolution of light and vertical mixing across a phytoplankton ice-edge bloom, Elem. Sci. Anth., 7, 20, https://doi.org/10.1525/elementa.357, 2019.

Ras, J., Claustre, H., and Uitz, J.: Spatial variability of phytoplankton pigment distributions in the Subtropical South Pacific Ocean: comparison between in situ and predicted data, Biogeosciences, 5, 353-369, https://doi.org/10.5194/bg-5-353-2008, 2008.

R Core Team: R: A Language and Environment for Statistical Computing, R Foundation for Statistical Computing, Vienna, Austria, available at: https://www.r-project.org/ (last access: 2 December 2019), 2019.

Ricchiazzi, P., Yang, S. R., Gautier, C., and Sowle, D.: SBDART: A research and teaching software tool for plane-parallell radiative transfer in the Earth's atmosphere, B. Am. Meteorol. Soc., 79, 2101-2114, 1998.

Sakshaug, E.: Primary and Secondary Production in the Arctic Seas, in: The Organic Carbon Cycle in the Arctic Ocean, edited by: Stein, R. and MacDonald, R. W., Springer Berlin Heidelberg, Berlin, Heidelberg, 57-81, https://doi.org/10.1007/978-3642-18912-8_3, 2004.

Smith, R. C. and Baker, K. S.: The Analysis Of Ocean Optical Data, in: SPIE Ocean Optics VII, edited by: Blizard, M. A., vol. 489, 119, https://doi.org/10.1117/12.943295, 1984.

Sosik, H. M. and Olson, R. J.: Automated taxonomic classification of phytoplankton sampled with imaging-inflow cytometry, Limnol. Oceanogr.-Meth., 5, 204-216, https://doi.org/10.4319/lom.2007.5.204, 2007.

Suggett, D. J., Moore, C. M., Geider, R. J., Perkins, R. G., Kromkamp, J. C., Serôdio, J., Lavaud, J., Jesus, B., Mouget, J. L., Lefebvre, S., Forster, R. M., Suggett, D. J., Moore, C. M., Geider, R. J., Perkins, R. G., Kromkamp, J. C., Serôdio, J., Lavaud, J., Jesus, B., Mouget, J. L., Lefebvre, S., and Forster, R. M.: Chlorophyll $a$ Fluorescence in Aquatic Sciences: Methods and Applications, Springer Netherlands, Dordrecht, https://doi.org/10.1007/978-90-481-9268-7, 2010.

Tremblay, J.-É. and Gagnon, J.: The effects of irradiance and nutrient supply on the productivity of Arctic waters: a perspective on climate change, in: Influence of Climate Change on the Changing Arctic and Sub-Arctic Conditions, Springer Netherlands, Dordrecht, 73-93, https://doi.org/10.1007/978-14020-9460-6_7, 2009.

Verin, G., Domine, F., Babin, M., Picard, G., and Arnaud, L.: Metamorphism of Arctic marine snow during the melt season. Impact on albedo, The Cryosphere Discuss., https://doi.org/10.5194/tc2019-113, in review, 2019.

Wassmann, P., Ratkova, T., Andreassen, I., Vernet, M., Pedersen, G., and Rey, F.: Spring Bloom Development in the Marginal Ice Zone and the Central Barents Sea, Mar. Ecol., 20, 321-346, https://doi.org/10.1046/j.1439-0485.1999.2034081.x, 1999. 